I.

THE EXCAVATION OF THE SCULPTOR'S CAVE, COVESEA, MORAYSHIRE. BY MISS SYLVIA BENTON, M.A., F.S.A.SCOT.

The cave is situated $1 \frac{1}{2}$ mile due north of Gordonstoun House, 6 miles north of Elgin, on the south shore of the Moray Firth. It takes its name from the so-called Pictish sculpturings outlined on the walls and published in Sculptured Stones of Scotland and Early Christian Monuments of Scotland.

When I obtained permission to see these in 1928, my companion, Miss Mollie Hair, called my attention to the fact that the floor was strewn with human bones. A knife stuck into the soil showed fatlooking occupation earth.

The late Sir William Gordon-Cumming, Bart., was sympathetic to our projects and readily gave us permission to make a further examination. A week's work at trial trenches gave us objects of Bronze Age and Roman date, and a hope of stratification, though we then had no idea of the richness of the deposit.

The following year Sir William and his son, the present Sir Alastair, with wonderful archæological interest and a most unusual generosity, put at my disposal the tools of the Gordonstoun estate and a team of four men led by Mr Charles White.

When I started cave digging I sought in vain for technical advice. I should like to record here a few hints gained from my own experience.

A dump is always a nuisance, but inside a cave it produces intolerable confusion of mind. Everything was put on a barrow and taken into the daylight. Here we soon learnt that the top soil was full of small bronzes which were quite invisible inside. Once on a barrow the earth might as well be put through a sieve. The men used this even when examining material which could not be riddled, such as clay. Each received his portion on the sieve and knew whether he had examined it or not.

Layers had been made in haphazard fashion in the top stratum by burning and trampling on the various floors. Owing to their irregularity and the friable nature of the shingle, these were useless for stratification. It was, however, found that a spade inserted above a floor went through easily and safely. If it was an inch too high or too low considerable force had to be exerted, and there was great danger of breakage. In view of the frailty of the invisible bronze this observation was of the greatest assistance to us.

VOL. LXV. 
The same system was adopted when dealing with much of the clay. Layers of sand were interspersed among it, and the spade ran easily among these. Tearing lumps of clay to pieces hour after hour is a most severe test of human patience. In $1929 \mathrm{I}$ had the advantage of the help of Mr David Wernham, who worked most manfully at these and other ungrateful tasks such as washing bones.

We missed him very much in 1930 , when we dealt even more faithfully with the clay. Sir Alastair again gave me the same team, and, as in 1929, we worked eight hours a day for five weeks.

\section{The Cave.}

The cave faces north, looking across the Firth to the Caithness hills (fig. 1). The sun never touches it, and a north wind made sieving at the entrance an unpleasant proceeding.

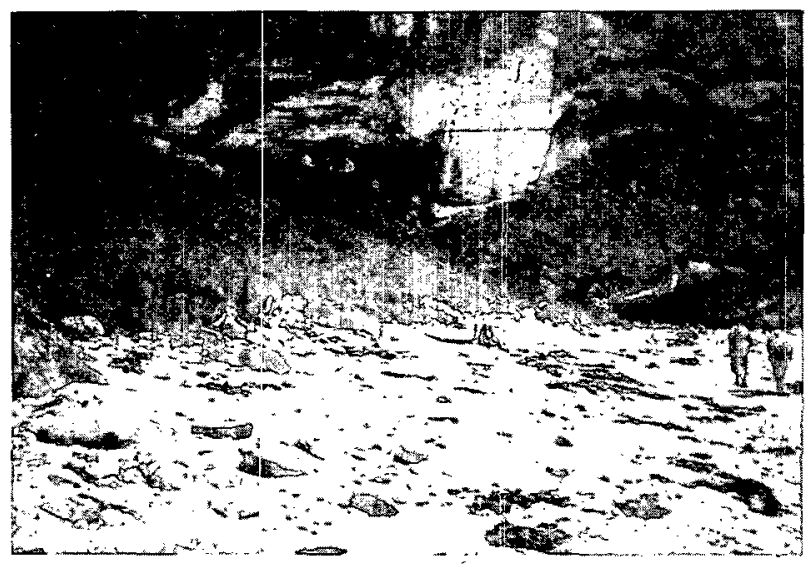

Fig. 1. Sculptor's Cave, Covesea, Morayshire.

Even now it is difficult to find and difficult to reach. It is cut off at high tide in stormy weather; on two occasions I wondered whether I should climb round without being drowned.

At the time of our earliest inhabitants, when the sea was little below the level of the passages, access could only have been possible at low tide. It must then have been a much less comfortable, though an even more secluded, residence than it is to-day.

The cliffs are red sandstone, and have been used for quarrying.

The cave itself, as shown on the plan made by $\mathrm{Mr} \mathrm{W}$. Whittet, is about 90 feet long and 40 feet wide (fig. 2). Since the plan was made we have cleared another 10 feet of roof. There is a passage behind going 
EXCAVA'ION OF 'THE SCULPTOR'S CAVE, COVESEA. 179
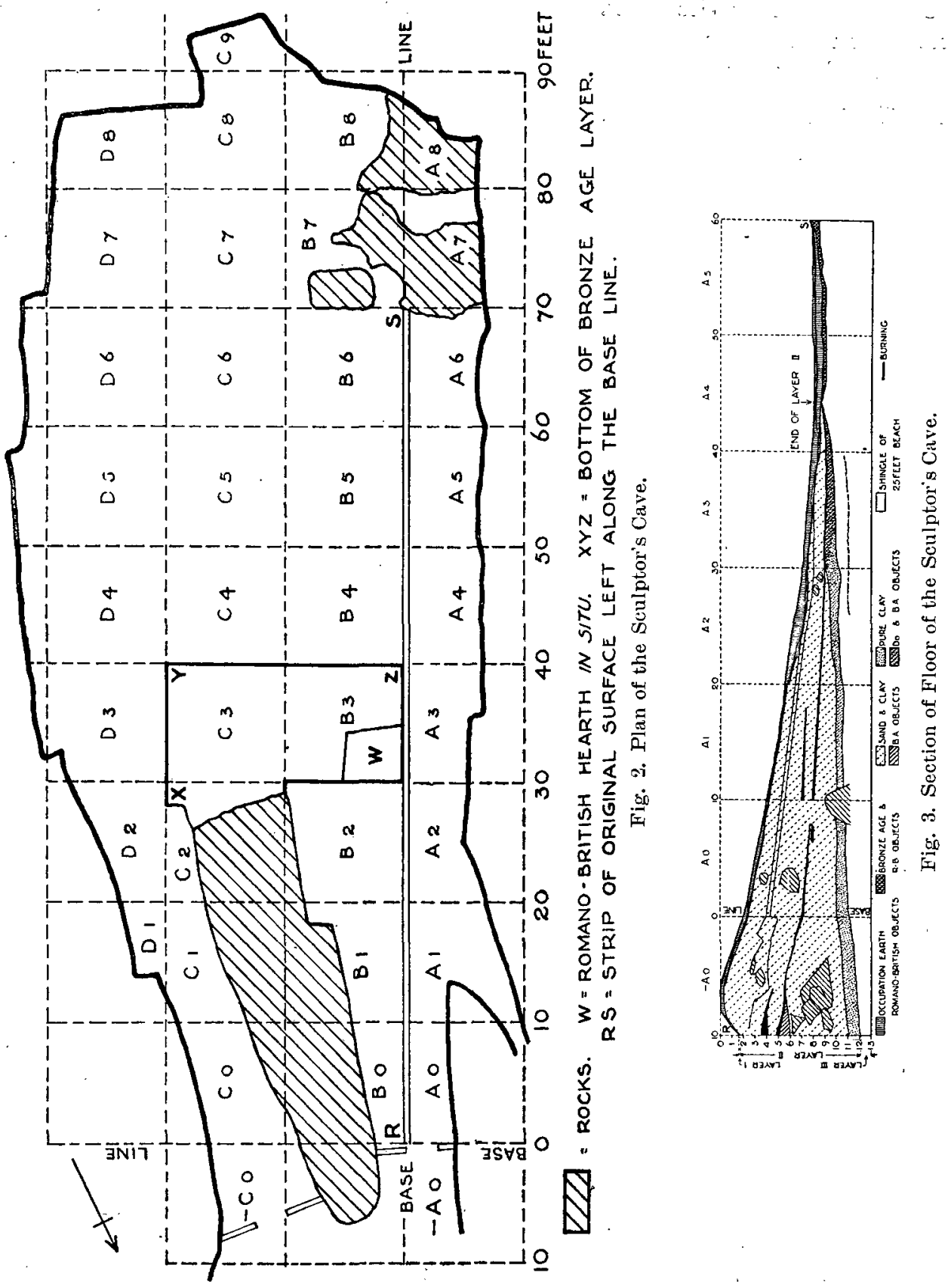
some 30 feet into the rock. Progress along this is by rolling, and it has not been shown on the plan. The two passages at the entrance are separated by a wall of rock. Falls of rock have occurred at various times in the south-west corner and outside. The surface of the rock is friable and some of the old sculptures are much decayed.

$R S$ is a strip of the original surface left along the base line, $\mathrm{XYZ}$ is the hard crust below the Bronze Age layer. $W$ is a Romano-British hearth left in situ above the Bronze Age layer. Strips of layer 2 have been left along the inside wall of both passages and in $-\mathrm{Co}$. A good deal of excavation has been done outside the cave. The height above sea-level was found by Major Sleight, R.E.

\section{The Strratification.}

There are three main layers of stratification (fig. 3).

Layer 1, Occupation Earth.-This extends over the whole cave, varying in depth from 2 inches to 2 feet. It is composed of the black of many fires mixed with sand, gravel, and débris. As described in the introduction, it is divided by floors hardened by fire and trampling. The gravel was so loose that coins were found in every layer, and pottery from different levels joined. Objects from the Bronze Age to a Viking rivet were found in this layer, but objects from the second century to the fourth century A.D. predominated. Bronze Age objects were found in it chiefly at the back of the cave and along the east side. They were not found within 40 feet of the entrance (ABCD 4) to base line.

Layer 2, Clay and Layered Sand.-These are mixed in the upper part. This dotted division below is composed of glutinous clay. It contains laminations from outside the door to (A 2), and has this character in crevices of the rock beyond this point. From 25 feet to 40 feet from the base line it is full of burnt black marks, charcoal, and Bronze Age objects. The clay dies out where the beach slopes up, about 45 feet from the door.

The Laigh of Moray to the south has just such clay, more than 60 feet deep at the brick-yards on the Elgin-Lossiemouth railway. As the links between Lossiemouth and Covesea lighthouse are recently made land, it is conceivable that the Lossie, flowing through the Laigh, entered the sea $2 \frac{1}{2}$ miles west of its present mouth. Probably the whole beach was muddy at this time when the sea had already started to retreat from the cave, and river and sea between them carried the mud into the cave. As the sea sank further, wind-blown sand covered the outside clay, but while (A 3) - (D 3) was still moist the Bronze Age people came and lived in it and trampled their goods and chattels into it. The black line of their smoke can be traced from (A 3)-(A 1) outside, where we 
found pottery like (A 3) - (D 3) pottery. (A 3) - (D 3) is separated from the Roman layer by a hard burnt floor which has proved impenetrable to the smallest coin, although it is only about 1 foot below the surface. Near the door it is about 6 feet down. The intermediate sand was almost barren above the clearly defined Bronze Age level. Opposite the rock wall, between the passages outside, a fall of rock seems to have crashed down on the inhabitants, leaving at least one crushed skull.

Layer 3.-The shingle of the 25-foot beach was barren except for the black line and a few bones.

Explanation of Marking.-Throughout, letters and numbers in brackets refer to the divisions of the cave. See plan (fig. 2). Objects stratified in the Bronze Age layer are marked 2nd. Objects not so marked are from the mixed layer.

HEARTH (B3).-The only structure we were able to identify was an apsidal hearth, set with curbs round part of the apse (fig. 4). Much credit is due to Edwards, the workman, who found and cleared it on his own initiative. I believe it to be complete. It was at the bottom of the Roman period layer, and we assured ourselves that no coins lurked in the moist clayey sand in which the stones were set,

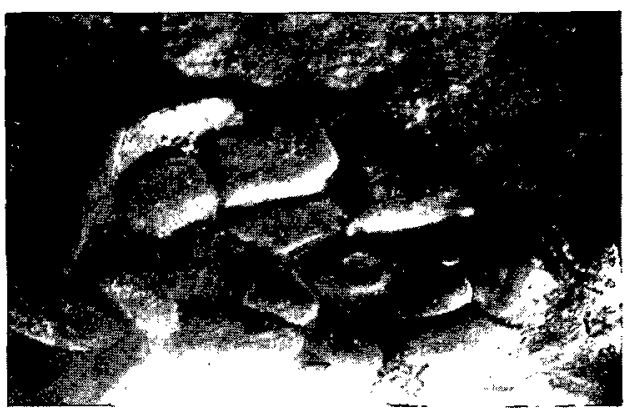

Fig. 4. Hearth in the Sculptor's Cave.

forming a barren layer above the Bronze Age clay. The photograph of the hearth found at Traprain ${ }^{1}$ seems very like ours. Mr Curle found another at Glenelg. ${ }^{2}$ There were traces of other such pavings. I ought, perhaps, to mention a large flat stone evidently used as a hearthstone before the Roman period. It has been left at the mouth of the cave.

\section{Bronze AGE.}

GoLd (C9).-Four pieces of False Ring-money (fig. 5, Nos. 1 to 4). These are small penannular rings, composed of a bronze core covered with gold. They have pointed terminals. They are in very bad condition, the core is disintegrating, and splitting the gold. Similar rings have been found in Scotland at Balmashanner, Forfar, ${ }^{3}$ and at Fuaraig Glen, Banffshire. ${ }^{4}$ They are common in Ireland. ${ }^{5}$ They are too small

\footnotetext{
1 Proc. Soc. Ant. Scot., vol. liv, p. 62, in the second century.

2 Ibid., vol. lv. p. 93.

${ }^{3}$ Ibid., vol. xxvi. pp. 182 ff. National Museum.

4 British Museum.

${ }^{5}$ Armstrong, Catalogue of Irish Gold Ornaments, plate xiv. pp. 271, etc.
} 
to have been worn as rings, and some, when found, showed traces of string, as in the bronze ring No. 7. Such rings were sometimes carried on bracelets. ${ }^{1}$. Measurements when found, ${ }^{5} 5$ by $\cdot 55$ inch; weight, 3.5. dwts. (D 2/2nd). - A similar ring (No. 5) was found hidden in the Bronże Age clay, beneath a shelf of the rocks. (B4/2nd).-Another (No. 6) was stratified in the Bronze Age clay: (B3/2nd).--A stratified piece of leaf gold, perhaps from another ring, is not illustrated.

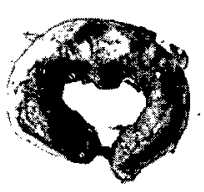

1
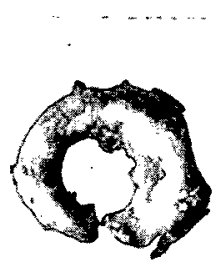

5

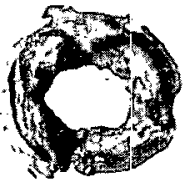

2

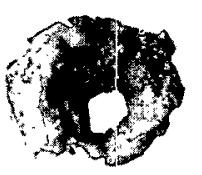

6

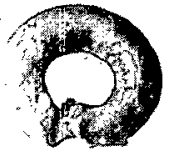

3

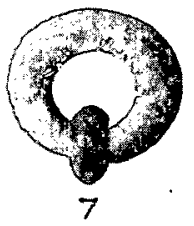

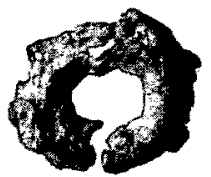

4

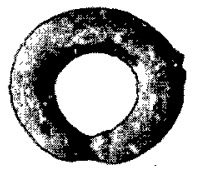

8

Fig. 5. Gold and Bronze Ring-money from Sculptor's Cave. $\left(\frac{1}{1}\right.$.)

Bronze (C9).-Two bronze rings (fig. 5, Nos. 7 and 8) were found along with the gold-plated rings of similar shape. Diameters, 7 and 6 inch. Weight, 3 dwts. I have only seen one other example from Torostan. ${ }^{2}$.

Bracelets (fig. 6 (D5)).-Penannular bracelet (No. 1), rectangular in section. The terminals are beaten up from the inside outwards to form irregular knobs. There are also two cast, horizontal ridges on the outside beside the knobs. A broken pair was found at Auchtertyre ${ }^{3}$ with three similar ridges. Otherwise I believe the Covesea pair to be unique in the British Isles. The type is certainly of foreign origin, coming originally from Upper Bavaria, ${ }^{4}$ but it went into Switzerland, ${ }^{5}$ and was there modified into forms almost identical with ours. ${ }^{6}$ (D 4).- The

1 British Museum, Bronze Age Guide, p. 54, from Ely, Cambs.

2 In the National Museum.

3 Proceedings, vol. ix. p. 435 . Not illustrated.

- Childe, The Bronze Age, p. 119.

s Anzeiger fiir Schweitzerisches Altertumskunde, xxix., Taf. xiii., No. 1.

- Landes Museum, Zürich, No. 1327--1. from the Lac de Zürich. It has three ridges at the end, but has also faint decoration all round. No. 1723-6 from Mörigen, which has one ridge on one side only. In shape it is identical with ours. 
EXCAVATION A'T THE SCULP'TOR'S CAVE, COVESEA. 183

other bracelet of the pair (No. 2). (C3/2nd).-Four fragments (No. 3), probably of one bracelet. ${ }^{1}$ These were stratified in the clay. The terminals are similarly beaten up from the inside. For analysis see p. 208. (A0/2nd).-One slightly swollen terminal was found above the Bronze
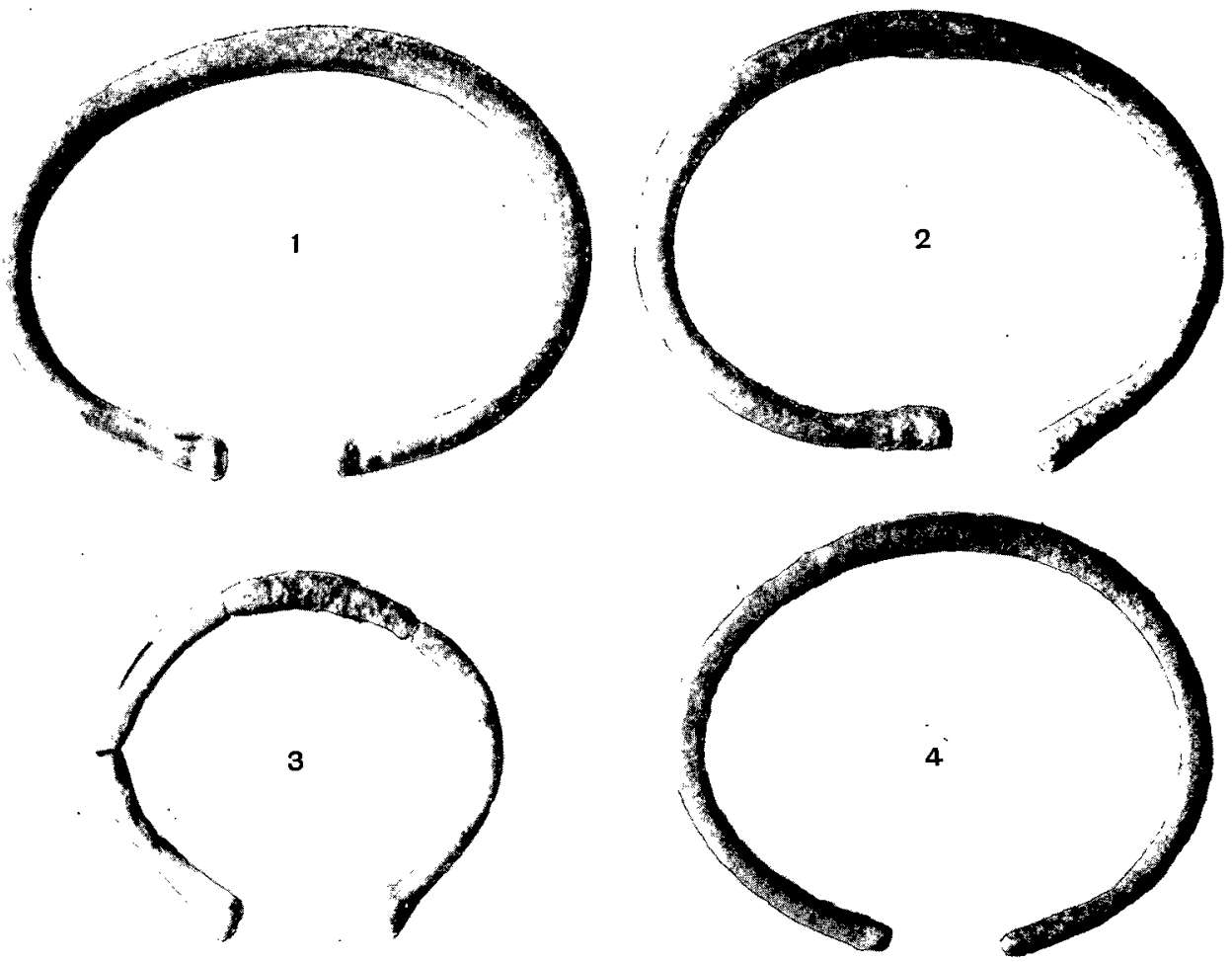

Fig. 6. Bronze Bracelets from the Sculptor's Cave. ( $\left.\frac{5}{6}.\right)$

Age layer, 3 feet below the surface outside the clay. This stratification is uncertain, and I attach no importance to it. (Not illustrated.) (D5).--Bracelet with very slightly beaten terminals (No. 4). Cf. Braes of Gight. ${ }^{2}$

I distinguish two types of penannular bracelets with swollen terminals. Both come originally from the Continent, ${ }^{3}$ but one seems to have been

${ }^{1} C f$. an unpublished example from Heathery Burn with a broken terminal. British Museum.

2 Proceedings, vol. xxv. p. 135.

3 A.S.A., vol. xxix., Taf. xii. and xiv., No. 3. 
developed in Ireland, and it is generally found in gold - the Irish material. In these the terminals have been beaten up regularly all round into a mushroom. In Scotland they are most frequent down the west

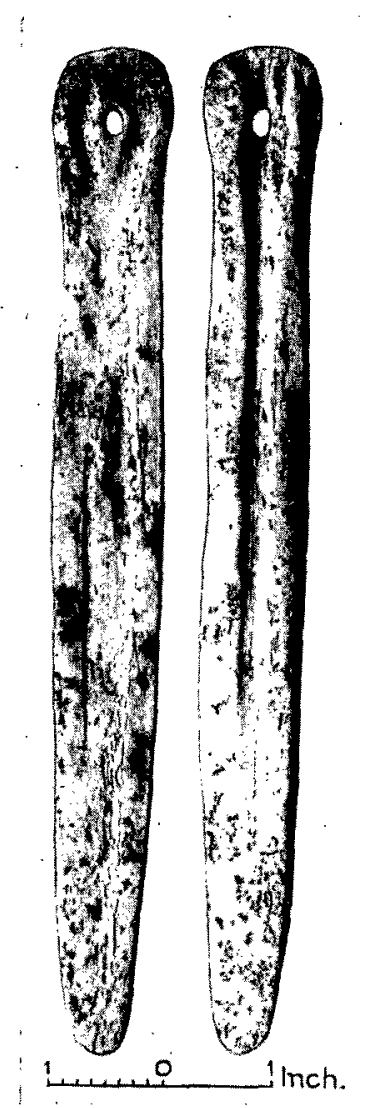

Fig. 7. Netting Needle from the Sculptor's Cave. coast, though they are found on the east in gold. ${ }^{1}$ Two in bronze have been found at Killin, ${ }^{2}$ Perthshire.

The second is our type, with terminals beaten from the outside to form a knob. These are much closer to their foreign prototypes, and those in bronze are confined in Scotland to the counties of Angus, ${ }^{3}$ Aberdeen, ${ }^{4}$ and the shores of the Moray Firth. ${ }^{5}$ In England one occurs at Heathery Burn Cave. $^{6}$ Thus we have a special kind of Swiss bracelet, concentrated in a limited area, and showing little or no signs of modification.

BoNE.-It has been found convenient to take all the larger bone instruments together, though, as is suggested below, some may be of Roman age.

(D7).-Instrument said to be a netting needle, probably made from the metatarsal of the reddeer (fig. 7). The hole is a natural nerve-hole which has been utilised, perhaps increased. The depressions down the centre are probably both natural, but they are increased artificially. There are lateral cuts down both sides of the depression and the point is worn. Several similar instruments, but without perforation, and retaining the outside of the bone and part of the process, were found at Heathery Burn Cave, ${ }^{7}$ and one other is in the Pitt Rivers' Museum, Oxford, from Jordan's Farm. Our specimen was found in the mixed layer, buried below a shelf of rock, along with

${ }^{1}$ From Hillhead in the National Museum. For Ireland see Armstrong, op. cit., plates xvi. and $x$ vii.

${ }^{2}$ Anderson, Scotland in Pagan Times. Bronze Age, p. 149. The fragment from Traprain appears to be of this type. Proceedings, vol. xlix. p. 165.

${ }^{3}$ Balmashanner, Proceedings, vol. xxvi. pp. $182 \mathrm{ff}$.

${ }^{4}$ Braes of Gight, Proceedings, vol. xxv. pp. $135 \mathrm{ff}$. Rehill, Proceedings, vol. i. pp. $138 \mathrm{ff}$.

5 Auchtertyre, Proceedings, vol. lvii. p. 154. Anderson, op. cit., p. 147; Wester Ord, Proceedings, vol. lix. p. 115, No. 6 ; Conage, Pettie, Proceedings, vol. iv. p. 299. A bracelet is also mentioned as coming from Conage, Banff, which I have not been able to trace.

${ }^{6}$ In the British Museum Not illustrated. It has one broken terminal. This shape in gold occurs at Alloa. Proceedings, vol. lvii. p. 164 (fig. 21), and at Patcham.

'British Museum, Bronze Age Guide, p. 49. 
the bone slice (fig. 9, No. 5). (C 3/2nd).-Similar, but much smaller (fig. 8, No.1). The transverse cuts are mostly on the point. Stratified in the clay.

We should, perhaps, notice that these tools have the shape of a leafshaped sword. There is a bone reproduction of a hafted dagger in the

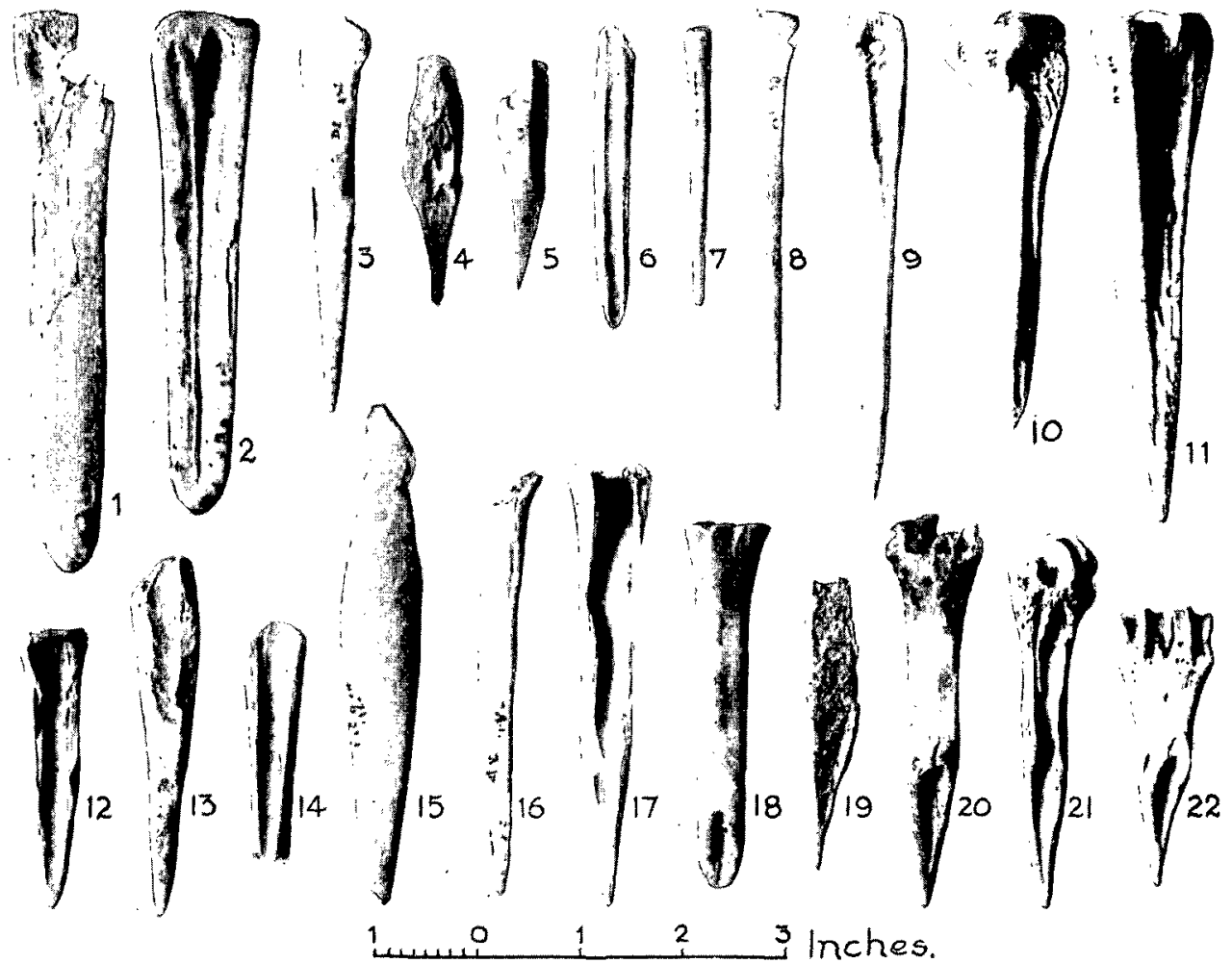

Fig. 8. Bone Scoops and Awls from the Sculptor's Cave. Nos. 1 to 14 and 17 from the Bronze Age layer.

Landes Museum in Zürich, said to be late-Neolithic, but one is tempted to suggest that it is typologically of the age of swords.

Fig. 8, Nos. 1 to 14 were found stratified in clay, No. 17 was found at the back of the cave. Nos. $2,6,10,11,12,14,17$ are of a very simple type. The bone, generally a metatarsal or a metacarpal, is split up the middle, one end is pointed and the inside may be polished (Nos. 2, 6, $10,11,14$ ), or may not (Nos. 12, 17). I could not find this type among the hundreds of bone instruments in the National Museum. Professor Childe showed me one lately found at Skara Brae, but said that the 
186 PROCEEDINGS OF THE SOCIETY, JANUARY 12, 1931.

type was unusual there. It resembled No. 2, and both may have been used for dressing skins. This type is found in the Swiss lakes. ${ }^{1}$ I believe that Nos. 6 and 14 are different ends of the same or similar spatulate instruments. There is a close parallel in Cambridge from Robenhausen. ${ }^{2}$

No. 9 is a strong needle with a close parallel from Heathery Burn, ${ }^{3}$ but there is one not unlike it in the Beveridge collection in the National Museum. No. 16 was found rather doubtfully stratified and is itself indeterminate. No. 15 has a freakish resemblance to a human face. Nos. 7 and 8 are common in any collection of bone instruments. The Broch people seem to have had two main types of instrument. (1) They took any splinter and pointed it, of which 4, 5, 13, 16, and 19 are instances. Such instruments are liable to occur anywhere at any time. (2) They cut off either end of a bone and pointed it, as in the case of $18,20,22.4$ It is notable that these did not occur in the Bronze layer and that the bisected type did not occur among the unmixed objects of the Roman period.

List of Instruments in fig. 8.-1. (C3/2nd) Netting needle? Probably metatarsal of red-deer. 2. ( $-\mathrm{B} 0 / 2 \mathrm{nd}$ ) Scoop. Probably proximal or anterior portion of metapodial of red-deer. 3. (D2/2nd) Punchers. Lateral metacarpal equus. 4 and 5. (B 3/2nd) Prickers. 6. (C 3/2nd) Scoop. 7. (B 3/2nd) Pin. 8. (B 4/2nd) Pin. 9. (D 2/2nd) Needle. 10. (-B 1/2nd) Pricker. Probably a fragment of the proximal end of the metacarpal of a red-deer. 11. (B 4/2nd) Pricker. Anterior fragment of the proximal end of the metacarpal of a red-deer. 12. (-B0/2nd) Scoop. Metacarpal of a red-deer. 13. (-B1/2nd) Pricker. 14. (C 3/2nd) Scoop. 15. (C 9) Pricker. 16. ( - A 1/2nd?) Pricker. 17. (C 7) Pricker. 18. (C6) Scoop: sheep or goat. 19. (C1) Pricker. 20. Not stratified. Pricker. 21. (C0) Pricker. 22. (B 10) Pricker.

I am indebted to Miss D. M. A. Bate of the Natural History Museum for these identifications. I take this opportunity to thank her for this and many other kindnesses.

Bone Needle.-(C9). This is a long, finely polished needle pointed at both ends (fig. 9, No. 8). For the shape, cf. a bronze needle at NidauSteinberg. ${ }^{5}$ There is nothing like it from Scottish sites. (D 3/2nd) Similar needles (fig. 9, Nos. 6 and 7).

\footnotetext{
${ }^{1}$ Keller, Lake Dwellers, plate iii., No. 20, from Meilen, has been cut short, but otherwise resembles No. 2. Steckborn, No. 16693, 40, 41, in Zürich, resemble Nos. 11 and 12 . I have not been able to trace any other examples from the British Isles. I have seen one from Macedonia and some from Thrace (unpublished information by the kindness of Miss Lamb).

Ethnological Museum, No. 24, 667 A.

Soc. cit.

- Wace and Thompson, Prehistoric Thessaly, p. 148, from Tsangli and Tsani. It is common at Glastonbury and in the Zürich Museun.

${ }^{5}$ Keller, Lake Dwellers, plate xxxvi., No. 13.
} 
EXCAVATION OF THE SCULP'TOR'S CAVE, COVESEA. 187

(D7) Perforated Slice.-This has been attributed to the Bronze Age because of its connection with the netting needle. Nothing exactly
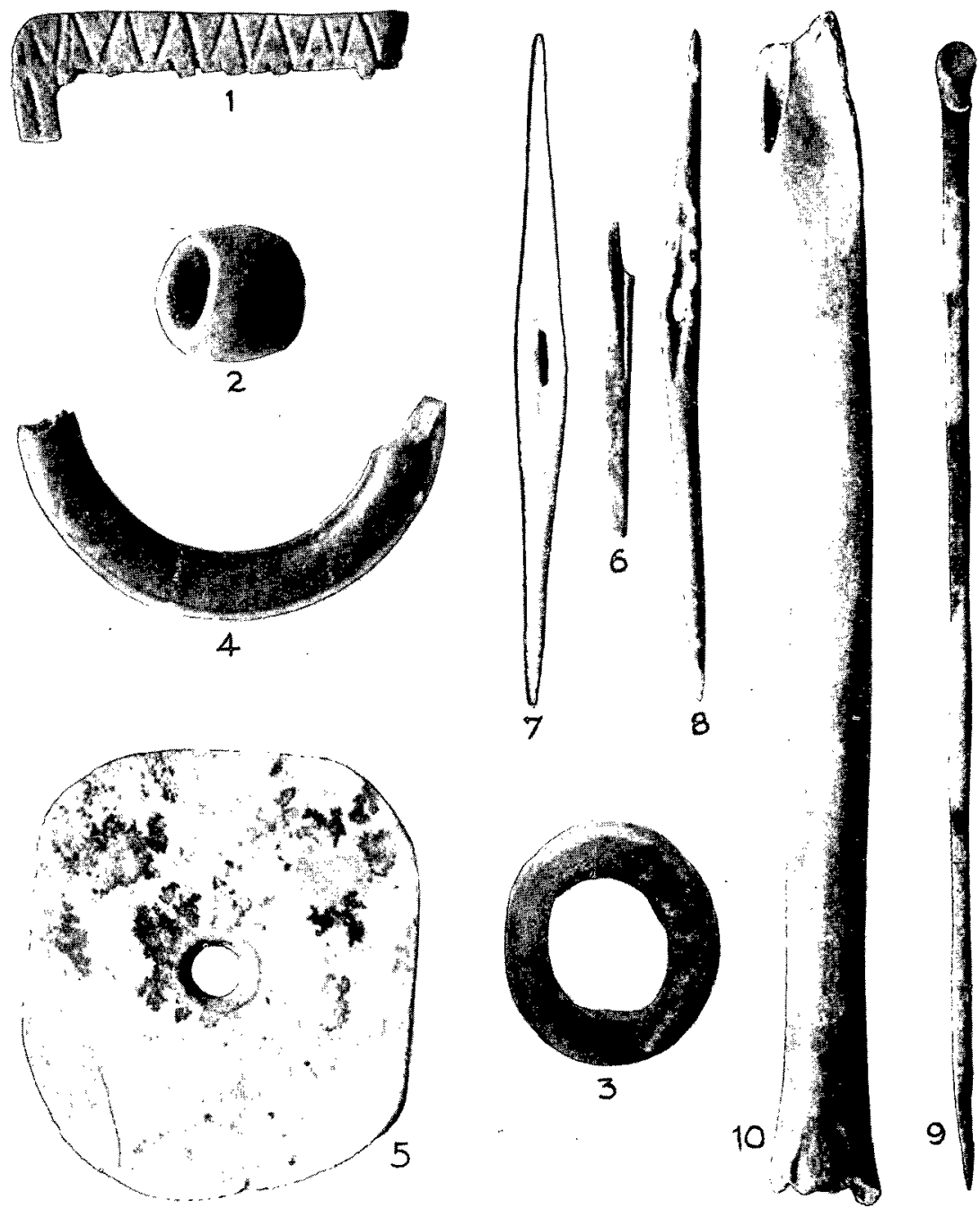

Fig. 9. Bone and other Objects from the Sculptor's Cave. ( $\left(\frac{1}{1}.\right)$

like it has been recorded, though there are some coarser parallels from the Beveridge collection. ${ }^{\text {It }}$ is rectangular, so that it cannot be a whorl 1 From Tota Dunaig and Bealach Ban, both in North Uist. 
(fig. 9, No. 5). I know of no other instance of this shape. Perhaps it is an ornament.

Classified List of Bone Instruments.

Scottish or Swiss.
$\quad$ Fig. 8.
18. (C 6$)$
20. (not stratified)
22. (B 10)

Swiss.

Indeterminate.

Fig. 7.

Fig. 8.

5. (D 7)

Fig. 8.

1. (C3/2nd)

2. $(-\mathrm{B} 0 / 2 \mathrm{nd})$

6. (C 3/2nd)

10. (-B 1/2nd)

11. (B 4/2nd)

12. $(-\mathrm{B} \mathrm{0} / 2 \mathrm{nd})$

14. (C3/2nd)

17. (C 7)
7. (B3/2nd)

8. (B 4/2nd)

15. (C9)

16. (-A 1/2nd)

21. (C 0$)$

9. (D 2/2nd)

19. (C 1 )

3. (D 2/2nd)

4. (B3/2nd)

5. (B3/2nd)

13. (- B 1/2nd)

Fig. 9.

6. (C9)

7. (D 3/2nd)

8. (D 3/2nd)

Out of twenty-six instruments, twelve are certainly foreign and a good many more may be foreign.

(A 0/2nd).-The basal portion of a shed antler of a red-deer (Cervus elaphus), with brow tine missing. Miss Bate writes: "In my opinion it has undoubtedly been artificially worked-shown by some sharp incisions at the distal broken end as well as by the curious excavations (worn smooth by thongs, possibly) at the proximal end of the antler." The excavations are three in number, and show an unexpected regularity. The whole bone is much worn, the usual vertical corrugations being missing. Mr Reginald Smith compares bone chopping-blocks or anvils from L'Aquina, ${ }^{1}$ and, in truth, this tine could be fixed rather comfortably into the ground. When the L'Aquina bones had been a little worked, there were cuts as from a sharp instrument: After further usage the surface became not unlike our excavations. They do not, however, occur in threes or on raised blocks or in horn. Worst of all, I am loth to admit a Mousterian product among our Covesea finds, even although it was found 2 feet below the Bronze Age level, just inside the door.

PotTery : Bronze Age.-In quality the pottery resembles that of the

${ }^{1}$ Henri-Martin, L'Evolution du Moustérien, plate lix. 
brochs, but it is not unparalleled in pottery of Neolithic and Bronze Age times in the Zürich Museum.

It is coarse; most of it contains large stones, like garnets in appearance, e.g. pots $\kappa, \lambda, \imath, \eta$. Some of it contains large white particles that seem to be shell, $\theta, \mu$, . The outside surface rasps like a file when the hand is drawn over it, particularly pot $v$. The only pot that shows an attempt at levigation is $\xi$. The inside of these vessels is generally smooth, notably so in the case of $\delta$ and $\epsilon$; all except $\eta$ are more or less blackened, and scraps of food often appear.

Almost the only shape seems to be a pail-like cooking - pot, with a rim which projects slightly inside (fig. 10). The pot curves out slightly below the rim. All bases preserved are flat. For rims see fig. 11. $\delta$, fig. 10, has been restored with slightly too wide a base. $C f$. fig. 11, No. 5 .

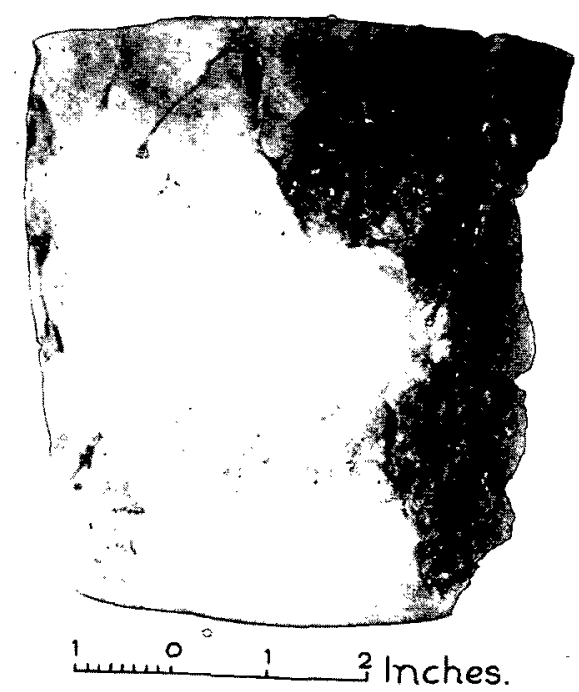

The pail is indigenous to Great Britain; it appearsin stea tite urns from Orkney ${ }^{1}$ and in undecorated transition pettery from Chastleton, ${ }^{2}$ Oxfordshire. The rim is

Fig. 10. Bronze Age Cooking-Pot from the Sculptor's Cave.

essentially like those of the cremation urns. I am not aware that the two have been found in conjunction in this country. They are to be seen in the Zürich Museum from Neolithic times to Hallstatt, I. ${ }^{3}$

1 Anderson, Scotland in the Iron Age, p. 73, fig. 57, from Fair Isle.

2 To be published.

3 Neolithic, No. 6223, from (Berne) Neuville-Chavannes. It is unlevigated, but smoother than our pottery. The ware is grey and decorated with nail marks.

Bronze Age: Lac de Zürich. The same rim, shape, and size continue unchanged. At least half a dozen vases might be quoted, though most have some decoration. No. 852, No. 1419, from Wollishofen. See also Mitteilungen der Antiquarischen Gesellschaft in Zürich, xxix., part iv., plate vii., No. 29.

Mörigen, No. 6287, found with leaf-shaped swords.

Grandson-Courcelettes, No. 6624. This urn may be wheel made; it is grey-black and polished. It is found with winged axes, antennæ sword, and open-work razors. It has lines incised round it, and a trace of such a line is shown on the pot on plate.

Hallstatt, $I$., Wangen Grave 4. It is of greyish-yellow unlevigated clay. It is hand made and undecorated. It was found with a bronze girdle. 
$\delta$. This pot was found mostly at the back of the cave (fig. 10), but two pieces, which may join, were found 6 feet down in $(-\mathrm{B} 0)$. At any rate their fabric is identical. The rim is flattened horizontally. $C f$. the rim of $\epsilon$ No. 6 on fig. 11. The colour is brick-red-shading to black. Restoration by Mr Young.

c. Rim, fig. 11, No. 6. -This pot was also found at the back of the cave, and has a similar rim and colour.

ל. (D3/2nd).-This pot was found in woeful disintegration at the
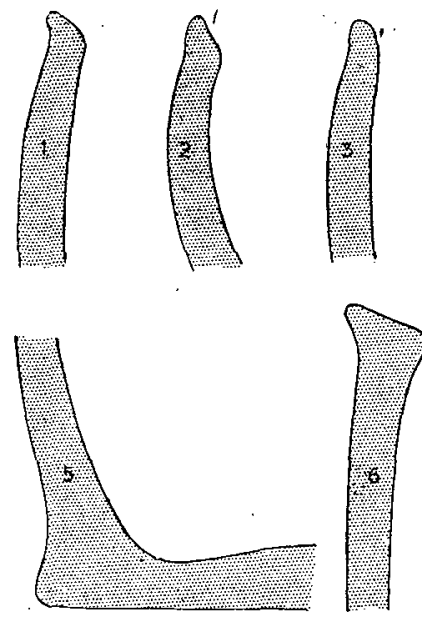

Fig. 11. Sections of Rims and Base of
Bronze Age Pottery from the Sculp-

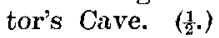
bottom of the Bronze Age layer. Some of it is indistinguishable from the last.

$\eta$. This pot was found in the clay of (D 3/2nd) and (D2/2nd). The rim is similar to fig. 11 , No. 7 , showing a distinct slope down towards the inside. It is of a bright red fabric that may be an attempt to reproduce a Hallstatt pigment.

o. Rim, fig. 11, No. 7.-This pot was found with a mutton-bone inside it and a crushed skull outside it in (-B1/2nd) under fallen rocks. The rim slopes more than the last. Though much of it survives, it has not been possible to complete it. It is reddish in colour, with white bits and garnets.

ı. Rim and base, fig. 11, Nos. 1 and

5.-Rim somewhat smaller than the last. Very rough. Yellowish grey.

$\kappa$ and $\lambda$. Rim, fig. 11, No. 2.-Found in (B3/2nd and C3/2nd). The rim is similar to the last. The surface varies so much that two numbers have been given in case the fragments represent two indistinguishable pots: grey with garnets.

. Rim, fig. 11, No. 4.-This is the only incurving rim except for one rather amorphous fragment. It is also the thickest in fabric and contains big bits of skull. It is light pink in colour. $C f$. one at Traprain, ${ }^{1}$ which may not be out of place in the sixth layer.

$v$. Rim similar to $\kappa$ and $\lambda$. This is dark red, with the surface of a nutmeg grater (D 2/2nd).

छ. Rim, fig. 11, No. 3.-The shape of this rim is more like an Iron Age rim than those we have been considering, and the fragment drawn was 
EXCAVATION OF THE SCULPTOR'S CAVE, COVESEA. 191

found in the first layer in (B5), but other fragments of undoubtedly the same pot were found well stratified in (B 4/2nd).

STONE.-(C3/2nd) Hammer-shaped piece of bored red sandstone with a channel on one side (fig. 12). It is hard to see what purpose this object could have served. Perhaps it was hung round the neck as an ornament. In west Ireland they had a way of boring granite ${ }^{1}$ for an equally unknown purpose. Sandstone hammers are found in Scotland, but this stone, less than 2 cubic inches in size, would have been quite useless.

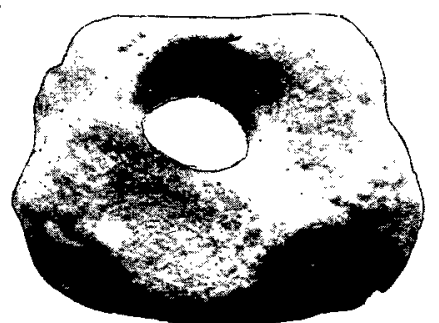

Fig. 12. Perforated Stone from the Sculptor's Cave. ( $\left(\frac{1}{1}.\right)$

(B9) Broken red flint-knife. A yellow flint-scraper was found in (C3) area, but the depth is uncertain.

\section{Roman Phriod.}

Bronze Rings.-Fig. 13, No. 7 (B 3), is a coiled ring in very bad condition. It is common for a long period. Nos. 8, 9, 10, 11, 13 are small rings. There are fragments of several others not illustrated. No. 12 (B3) is a piece of knotted wire which is doubtless common, and has a parallel in Saxon times in the Ashmolean Museum. No. 14 (C0) may be a piece of chain armour. ${ }^{2}$ Fig. 14 (B7) is a plain penannular ring. It may belong to the Bronze Age.

Brucelets (D 2).-A broken bracelet of rectangular section. The surface is corroded, but it appears to have had some pattern. One terminal is a hook, the other is broken. This fastening is common on Roman sites. ${ }^{3}$ (B3) Probably a fragment of a twisted bracelet. $C f$. Traprain ${ }^{4}$ and Colchester B. M. (B 5) Piece of a chain with spirals.

Pendants (fig. 13, Nos. 15 (D 2), 16 (A 4), and 17 (D 4)).-It is suggested that these may be tags for legionaries' belts of an early type, where the straps are cut into small strips, each with a tag. Ritterling thinks that 150 B.c. is a terminus ante quem for these. ${ }^{5}$ They are in bad condition, and Mr Young informs me that No. 17 is stained with leather. Nos. 18 (A 4) and 19 (C5) are little pendant saucepans or bullæ which date from sixth century Greece onwards. ${ }^{6}$ Mr Beck quotes an example from Harlech said to be Roman and some from Bologna. ${ }^{7}$

Fig. 15, No. 1 (C6).-A hook-like object. The upper end is filed down,

1 Private collection.

${ }^{2}$ Curle, Newstead, p. 161, plate xxxviii., figs. 8, 10. The mesh of the Govesea example is coarser.

${ }^{3}$ On Colchester. In the British Museum. ${ }^{4}$ Proceedings, vol. lvii. p. 198, No. 11, 3rd level.

5 Ritterling, Hofheim, vol. xv., No. 73; vol. xi., Nos. 56, 57, 66. Bushe-Fox, Richborough, vol. ii. p. 48 .

${ }^{6} C f$. the silver strainer at Traprain, Proceedings, vol. lvi., fig. 20, No. 9.

${ }^{7}$ Del Picino and Montegiragio. 
192 PROCEEDINGS OF THE SOCIETY, JANUARY 12, 1931.

the lower broken. It is of stouter make than most of the objects of this period. Nos. 4 (A 5) and 3 (D 4). Probably the bolt and key of a barrellock. The bent end of No. 3 is a hollow square which could run up
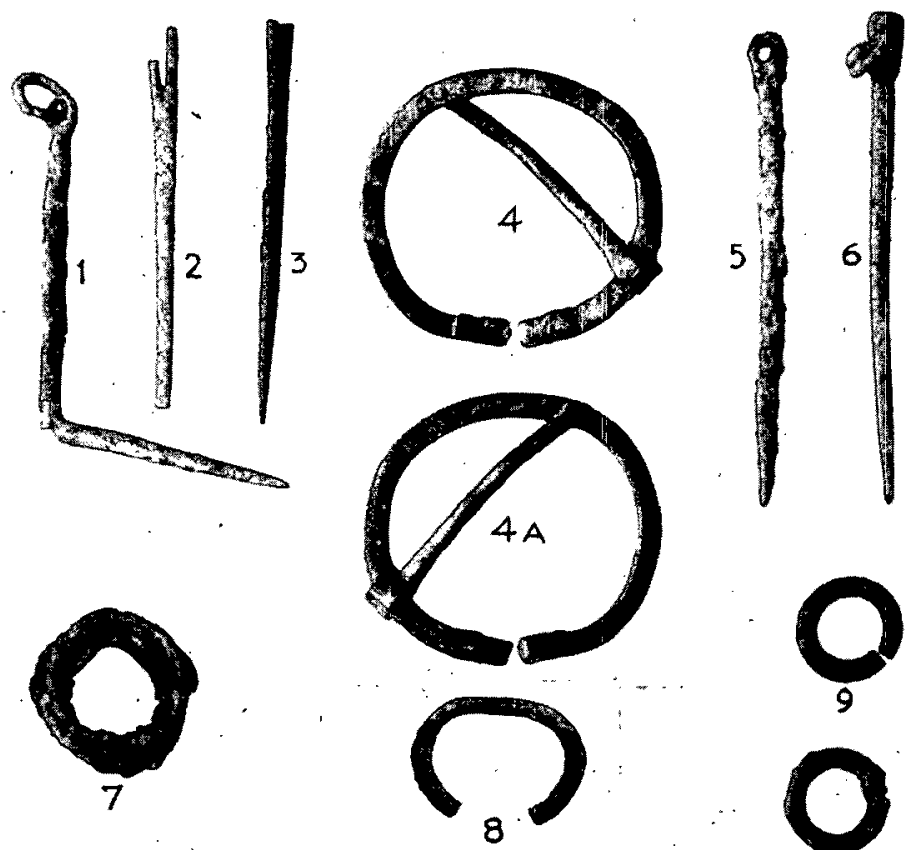

8

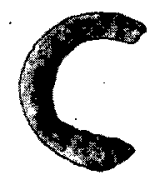

11

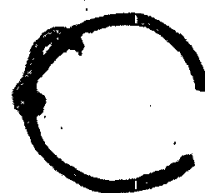

12

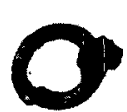

13
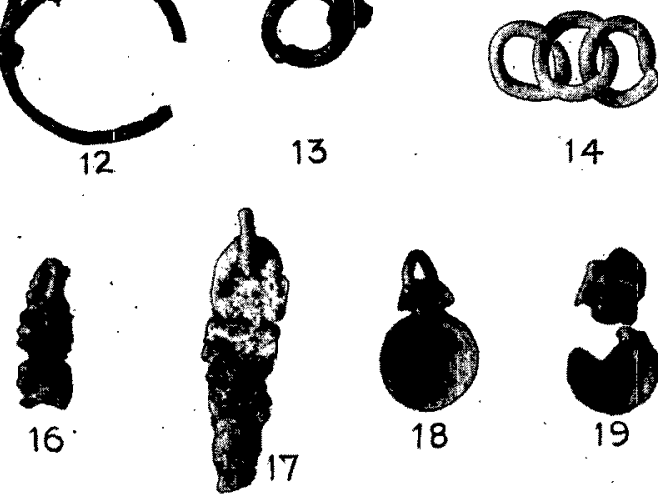

14
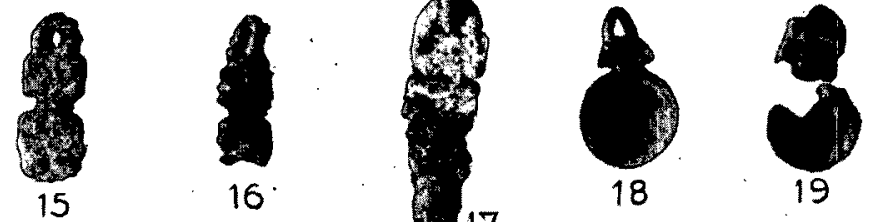

Fig. 13. Bronze Objects of the Roman Period from the Sculptor's Cave. (1.) 
No. 4, so that the springs on both sides could be compressed and then withdrawn. A similar bolt without the spring was found at Traprain. ${ }^{1}$ No. 2(A 0 ) seems to be a sword guard or scabbard top. A straight-faced bronze guard with a Celtic frill is found on an iron sword at Newstead, ${ }^{2}$ and plain bronze bands are found on iron swords in the British Museum and at Oxford. A smaller mounting occurs in the second century at Traprain. ${ }^{3}$ Mr Curle thought it out of place and attributed it to the Bronze Age. Covesea supports his stratification as $(\mathrm{A} 0)$ is at least 5 feet above the Bronze Age level. No. 5 (A 1) is an unexplained object which was perhaps inscribed. "TRES" is a very uncertain reading.

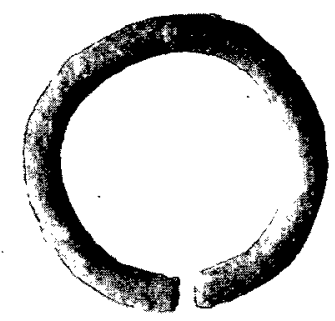

Fig. 14. Bronze Penannular Ring from the Sculptor's Cave. (1.)

Bronze Wire Beads (D 3).-One complete bead and several fragments were found. Mr Beck writes: "These, although found in Roman and Saxon period, in this country were rare at that date." + From its position
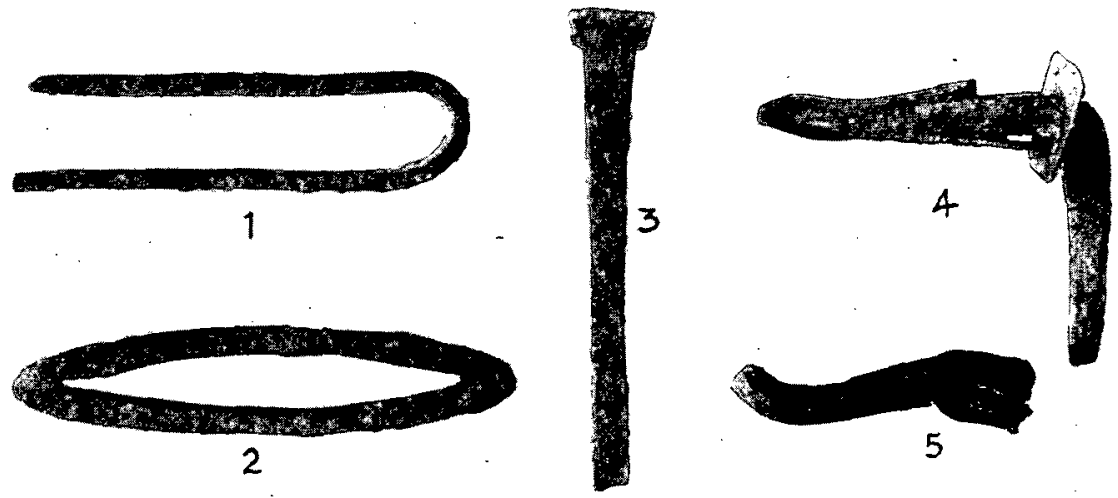

Fig. 15. Bronze Objects of the Roman Period from the Sculptor's Cave. (1.)

it ought to belong to the Roman period. There are four in the National Museum-two from Traprain, ${ }^{5}$ one from Jarlshof, ${ }^{6}$ and one from Dun Beag."

1 Proceedings, vol. lvii. p. 222, fig. 28.

2 Curle, A Roman Frontier Post, p. 185, plate xxxiv., No. 10.

${ }^{3}$ Proceedings, vol. lvi. p. 212, 1, p. 213.

4 Ashmolean Museum, from Wheatley Grave 27, Proceedings of the Birmingham Philological Society, vol. iv., part i., p. 179.

5 Proceedings, vol. lvi. p. 212, 1, p. 213. National Museum. VOL. LXV.

- National Museum. 13 
Fragments.-Small bronze hook (C8) and various fragments from different places, including broken pin stems.

Bronze Wry-necked Pins with Circular Heads.-These are among our most attractive finds. Such pins are not uncommon in Scotland and elsewhere, but their evolution and chronology is at present somewhat obscure. I cannot follow $\mathrm{Mr}$ Reginald Smith in his claim that the Keady pin, the Lingrow mould, and the Bowermadden pin are all the same. They seem to be three different pins.

The Keady pin, as illustrated, appears to have small corrugations all round (not two-thirds of the way), which I believe represent the thread wound round to keep the pin in position. ${ }^{1}$ The Lingrow mould has some decoration at the base, possibly like our No. 7, and the corrugations are half way to becoming pellets, as in Traprain, ${ }^{2}$ and Tents Muir, Fife. ${ }^{3}$ The Bowermadden pin is becoming a hand pin below, like our No. 5, and has corrugations intermediate between the Keady pin and the Fifeshire pin above. A chronology based on this misconception is not very promising, and when we apply it to Traprain we find the ringheaded pin, supposedly dated before them, ${ }^{4}$ present in all layers from the early second to the fifth century. ${ }^{5}$

It seems probable that there are more elements present in the evolution of this pin than Mr Smith would allow. It is a pity to leave out the sunflower pin, and I would suggest that the rolled pin with a crook in the neck, which the Swiss used to attach their sword girdles, ${ }^{c}$ cannot be neglected, especially as one of these girdles reached Braes of Gight. ${ }^{7}$

Leaving the earlier history for a future occasion, let us confine ourselves to the examples actually before us. Fig. 16, No. 1, seems the simplest and therefore, perhaps, the earliest type with one end of the cloth wound over the base. We must remember, however, that simple types had a way of persisting along with their more elaborate derivatives, e.g. the lap-over pin at Traprain, already quoted. ${ }^{8}$ No. 7 would come next, with three swathes of cloth at the base still looking like cloth. Nos. 8 and 9 are different stylisations of this motive. No. 2, with three definite pellets, develops from 8 into No. 3, the rose-pin. ${ }^{9}$ Nos. 4 ,

1 Proceedings, vol. xx. p. 348, where see references.

2 Ibid., vol. Ivii. p. 210 , No. 3.

${ }^{3}$ In the National Museum.

"Smith, op. cit., p. 347, "End of the first, beginning of the second century A.D." I think that in a subsequent paper on pins, "Opuscula ad Montelium," Mr Smith dated these earlier.

5 Proceedings, vol. lviii. p. 262, "Analysis."

${ }^{6}$ Neuchâtel Museum, from Auvernier. See also illustration in Keller, ed. Lee, plate xlviii. No. 8, from Estavayer. The ribbing below is unusual.

7 Loc. cit.

${ }^{8}$ Smith, loc. cit., Early Ness pin. 
EXCAVATION OF THE SCULPTOR'S CAVE, COVESEA. 195

6, and 10 are a stylisation of No. 9 into bars between pellets. No. 5 is the hand pin, which seems to go back to No. 7 .

These two last pins may be said to be dated at Traprain to the fourth century or later. ${ }^{1}$ The rose-pin only occurs there. Pellets and bosses
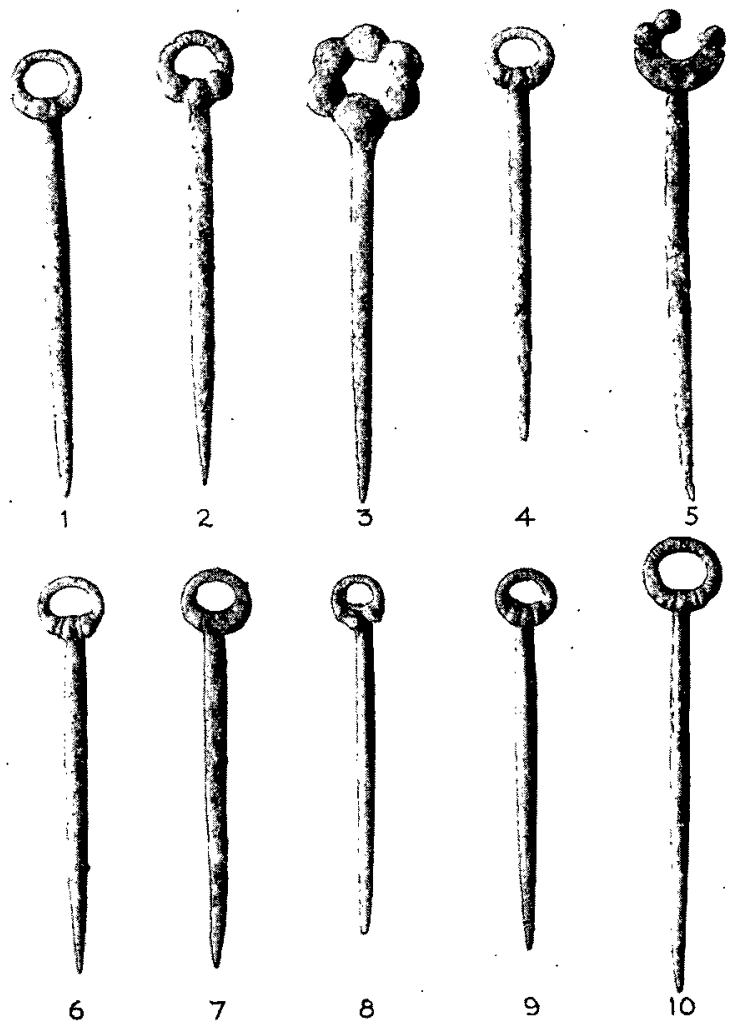

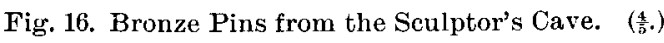

seem to have had, and I believe still have, an attraction for the inhabitants of East Scotland. It is the underlying principle of the decoration of the stone balls.

The hand pin must have had four pellets when unbroken. The two at Traprain have five and three pellets respectively. ${ }^{1}$

All these pins exemplify a love of severe symmetry of ornament which is now at any rate a national characteristic. Contrast the pin figured by. Mr Smith from sandy beds, or, still more, one in the Ashmolean Museum from Woodperry. ${ }^{2}$

\footnotetext{
'See Analysis, loc. cit.

${ }^{2}$ Archceological Journal, vol. iii. p. 120, fig. 19, No. 10, and p. 122.
} 
Nos. 4, 6, and 10 are paralleled by two pins from North Berwick in the British Museum and in the National Museum.

All the pins were found in the mixed layer in the following divisions:No. 1 (C 7), No. 2 (C 8), No. 3 (D 5), No. 4 not stratified, No. 5 (A 5), No. 6 (C 8), No. 7 (C6), No. 8 not stratified, No. 9 (C 8), No. 10 (C4).

I should like to date Nos. 3 and 5 in the fourth century and the others provisionally in the second century.

Zoomorphic Pins, fig. 9, No. 9 (C 7).-Large pin found inside a bird bone. The type is common at Traprain, where it is present in all layers. It was also found in earliest Newstead, c. 80 B.c. No development of type is apparent at Traprain. ${ }^{1}$ Fig. 13 , No. $6(\mathrm{D} 4)$ is a similar but smaller
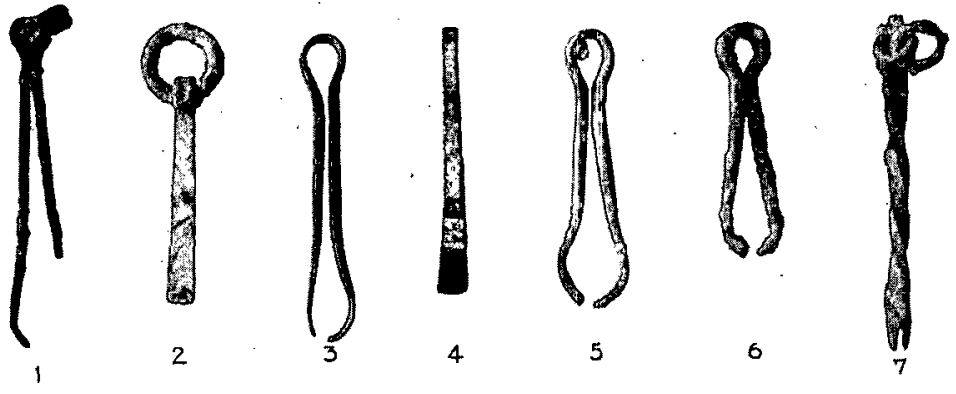

Fig. 17. Bronze Toilet Instruments from the Sculptor's Cave. (ca. 6. .)

example, except that it has ducks' heads on two sides. The form of attachment is the same as that on our coin 43, Roma. Cf. also our twisted grattoir, fig. 17, No. 7 .

Toilet Instruments, fig. 17, No. 1 (B 3).--Pincers with one end broken. This has the same attachment as the fourth-century coin, fig. 23, No. 43. No. 3(C5). With good surface and the spring still working. No. 5 (C 5). In less good condition. No. 6 (C5). In very bad condition.

No. 2 (D 1) seems to be a nail-cleaner. When it was shown on the screen a pattern of incised lozenges became visible.

No. 4 (B1) may also be a nail-cleaner. It is sharpened at both ends. A similar instrument was found in the early Saxon cemetery at Girton College. $^{2}$ For the pattern, $c f$. Traprain. ${ }^{3}$ No. 7 (B3). Grattoir of twisted wire. The head is zoomorphic, a bill being faintly visible below the double atachment rings.

1 Analysis, loc, cit.

${ }^{2}$ Hollingsworth and O'Reilly, The Anglo-Saxon Cemetery at Girton College, p. 20 (B) 4. Fox, Archoology of the Cambridge Region, plate xxvii,, 2, dated late sixth century, p. 248.

¿ Proceedings, vol. lvii., fig. 23, No. 1, fourth century, by stratification. No. 2 , fifth century, by stratification. Ibid, vol. Jv., fig. 21, No. 15; also late. 
These toilet instruments are common in the Bronze Age and in Roman and Saxon times.

Needles, fig. 13, Nos. 1 (D 4) and 5 (D 3).--Bronze needles of a usual type which is not found in Scotland. No. 1 with ring for attachment. No. 5, from its position, should be of the Roman period. Nos. 2 (C5) and 3 (D 5) fragments of another type.

Penannular Brooch, fig. 13, Nos. 4 and $4 \mathrm{~A}$ (B6).--This is a simple

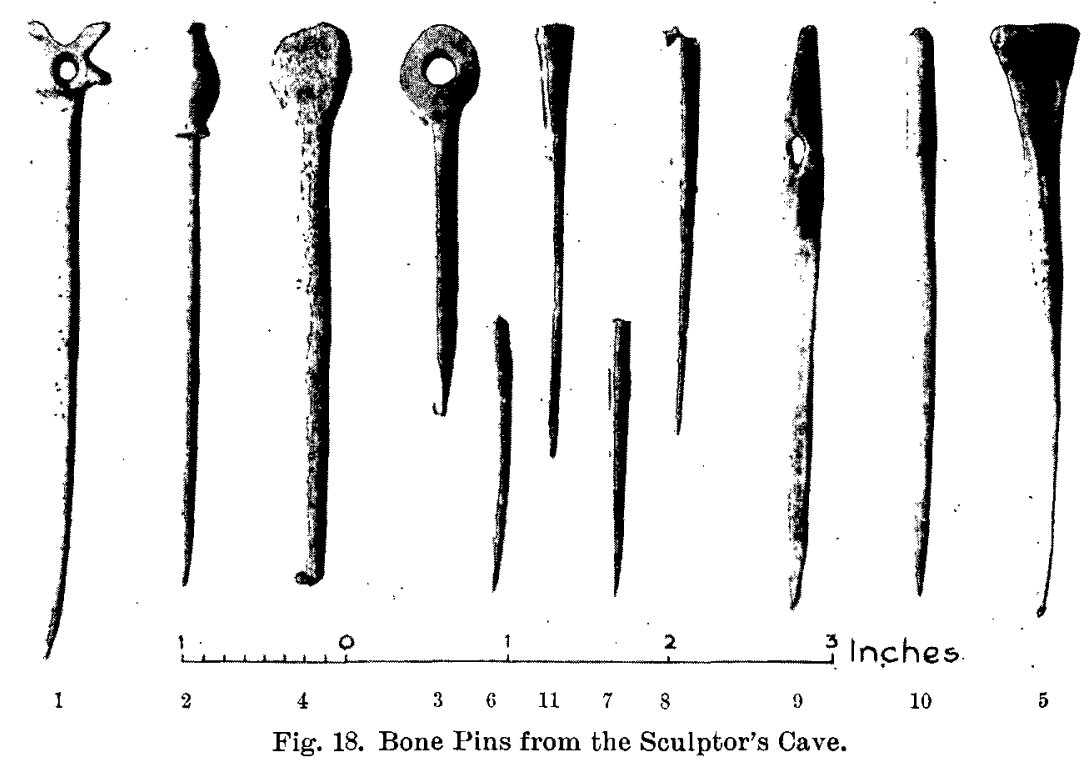

example of a pleasing type. Slightly zoomorphic terminals have been hammered back, and are not yet incorporated in the ring. It is rectangular in section, and lightly punched. It is impossible to hazard a date. ${ }^{1}$

Bone Pins, fig. 18, Nos. 1 (A 6) and 2, were found beside a hank of red hair. No. 1 is a pierced four-leafed clover, beautifully polished with punch marks between lightly incised diamonds on the stem. I know of no exact parallel, but the style is not uncommon in the brochs. ${ }^{2}$ Knife marks are clearly visible about the head. No. 2 (A 6). Barrel-shaped pin. This specimen is also finely polished and in excellent condition. The shape is fairly common in Roman sites in England. A knife seems to have been used on this head too. No. 3 (C 6). Ring-headed pin. Well

1 Cf. Girton, op. cit.; plate iii., also a ring at Traprain, Proceedings, vol. liv. p. 78, fig. 3.

2 Craig of Boyne, Banff, Proceedings, vol. viii. p. 290. 
polished on one side, but of rougher make. Knife marks to be seen round the head.

No. 4 (B 6).- Spoon. There is very little polish about this head. The side of the head suggests little slices with a knife, but there are no actual cuts, as in the last three examples. $C f$. Borness Cave. ${ }^{1}$ It has lost its point. No. 5 (C 7). This specimen differs very little from fig. 8 , No. 8. It is a little flatter at the point. Nos. 6 (A 5), 7 (D 4), and 8 (B 8) are broken points of pins. It has been suggested that such casualties frequently occurred in shell mounds in the extraction of shell-fish. There were enough limpets in Covesea to support this theory. ${ }^{2}$

No. 9 (B 7) is a type of needle very common in Scotland. An irregular hole has been bored in a slightly polished splinter. See the Beveridge Collection from North Uist in the National Museum. ${ }^{3}$

No. 10 (B 7), cf. fig. 8, No. 7.

Fig. 9, No. 10 (C8).-Bone Sheath. The pin, fig. 9, No. 9, was found inside it. Such sheaths are well known, ${ }^{4}$ and pins have sometimes been found inside. ${ }^{5}$

Fig. 9, No. 1 (D 4).-Fragment of a rectangular comb with chevrons engraved on it. There are knife cuts between the teeth. A straightsided rectangular comb is unusual. A semicircular one, also broken, and with a geometric pattern, comes from Kettleburn. ${ }^{6}$ It is probably to be dated fairly late with the Traprain and Girton toilet instruments. Fig. 9, No. 3 (C8). Flat bone ring. No knife marks are visible on this, so it may belong to the earlier period. It has clear polishing marks. ${ }^{7}$ Fig. 9, No. 2 (C 5). Bone bead. This is well made, but not highly polished as most of those of this size from Skara Brae. ${ }^{8}$ Fig. 9, No. 4 (B 7). Right upper incisor of a beaver. These are reported from Loch Nevis in the fifteenth century, but their remains are not common in Scotland. ${ }^{9}$

Beads and Glass, fig. 19, Nos. 1 to 7.-Amber, Nos. 1 and 2 (C7).-Mr Beck writes of No. 2: "The beautifully made annular bead appears to me to be pre-Roman, and probably to be of the same date as the two dark blue beads referred to later. The other amber beads are not sufficiently detinite to date." No. 3 (D 3). Irregular, with a tiny hole. No. 4 (B 6). The hole is of intermediate size. There is also a hole on one side, as

1 Proceedings, vol, x. pp. $490 \mathrm{fr}$. ; vol. xi. pp. $305 \mathrm{ff}$.

2 T. C. Lethbridge, "Shell Mounds and Winkle Pins," Archoologia Cambrensis, June 1928.

${ }^{3}$ Also Wester Broch and Keiss Broch, Caithness. In National Museum.

${ }^{4}$ Broch of Burray, Orkney, Proceedings, vol. xi. pp. 5 and 56.

${ }^{5}$ Keller, op. cit., plate xlii., 6 and 7, p. 290 . Thigh of a stork used as needle-case.

- Catalogue, p. 237. No illustration. Cf. Comb from Skail. Proceedings, vol. xxii. p. 284.

${ }^{7} \mathrm{Cf}$. a rougher ring from Archerfield. Proceedings, vol, xliii. pp. $265 \mathrm{ff}$.

s To be published. See also beads from Jarlshof and Westerbrock in National Museum.

Identification by Miss D. M. A. Bate. 
EXCAVATION OF 'THE SCULPTOR'S CAVE, COVESEA. 199

if some other ornament had rested against it. No. 5 (D3). Very small and irregular. No. 6 (D4). The condition of this bead is rather poor. The hole is small. No. 7 (D 3). This bead has a large hole and is roughly rectangular.

Glass.-The report kindly sent me by Mr Beck is here given in inverted commas. I have added a few notes on the Scottish material. All the weights are given by him.
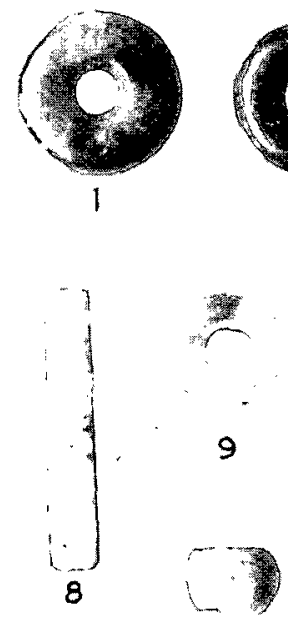

15

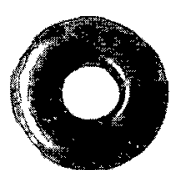

2

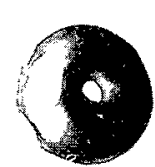

3

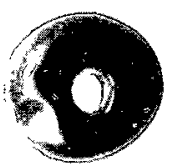

4

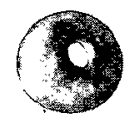

5

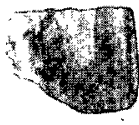

.11

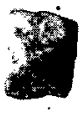

17

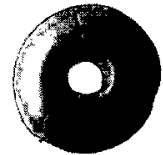

12

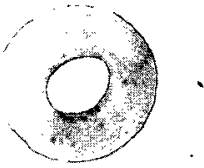

18
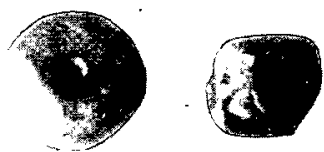

6 7

Fig. 19. Beads, etc., of Glass, Amber, and Jet from the Sculptor's Cave. (1.)

Fig. 19, No. 8 (C 7).-Long Square Cylinder.-Weight, 1.216 gramme; sp. g., 237. "This bead is made of a pale blue glass, in which I believe the colouring material to be copper. Beads of this glass, but usually spherical or oblate, are found at Lakenheath, Salisbury Plain, etc. I cannot date this bead, but expect it to be either Roman or Saxon. The form is not common, but I have met it in pre-Roman, Roman, and Saxon times. So far as $I$ can remember, $I$ have never met it in this glass."

Most of the square beads I have seen in England are larger. There is a broken bead of this size (its length cannot be determined) in dark blue glass from Traprain. ${ }^{1}$

1 Proceedings, vol. lviii. p. 269 , fig. 17, No. 5, from 2 nd level. 
Small oblate blue bead, No. 15 (A 5).-W Weight, 567 gramme; sp. g. about 2.2. "This bead, which is of practically the same glass as the last, is similar to beads from Salisbury Plain and other places in this country. The specific gravity, however, is lower, which may be due to hidden bubbles. Unfortunately we cannot exactly date them, but it seems probable that they are Roman or Saxon, when found in this country. On the Continent, in Bohemia, they date to about 100 B.c." Small annular green bead of clear glass, No. 9 (C6). Weight, 833 gramme; sp. g., 254. "A good example of ordinary bottle glass found both in Roman and Saxon sites." Cf. 'Traprain." Pentagonal cylinder in opaque green glass, No. 10 (D 3). Weight, 820 gramme; sp. g., 228. “A common type of bead, not infrequent in Roman times, would not be much earlier but might continue to Saxon times." In appearance this is very like a bluish-green hexagonal bead found at Traprain. ${ }^{2}$ Annular bead of clear green glass, No. 16 (C6). This is made from the hollow ring at the base of a vessel. The sides and end have been cut and smoothed. It is from a base, ${ }^{3}$ not a rim, as it expands horizontally in both directions; $c f$. a base from Traprain, ${ }^{4}$ which is called a rim in the text, but quite clearly expands almost at right angles on both sides. No. 17 ( $-\mathbf{A} 0)$. A chip of opaque red glass. "This is a glass coloured with copper, which is included in the form of minute particles of metallic copper." Single wave bead, No. 18 (D6). "White wave with four crests on a cobalt blue base." Weight, $2 \cdot 375$ grammes; sp. g., 2419. "This bead I consider is probably an early bead. The slightly higher specific gravity (compared with No. 19 below) may be due to the white wave, some of the white glasses being very heavy. On the other hand, the bead is lighter in colour, and there seems to be a tendency for these cobalt beads to have a higher specific gravity when the colour is lighter. In any case it has a lower specific gravity than any Saxon cobalt bead that I have tested. But it is not on account of the specific gravity that $I$ say it is early. The whole appearance suggests a pre-Roman date to me, although several such beads have been found with Roman remains in parts of England." Similar though not identical beads have been found at Newstead and Traprain. Large dark blue oblate bead, No. 19.(C 7). Weight, 4.233 grammes; sp. g., 2:386. “This bead, which is made from cobalt glass, is, I believe, pre-Roman, probably La Têne. The whole appearance and the colour agree much more closely with the early beads than they do with the later or Saxon variety of the same glass. Also, although there is not sufficient divergence in specific

\footnotetext{
1 Proceedings, vol. liv. pp. 66, 29, and 30 . Second century A.D.

${ }^{2}$ Ibid., vol. lvii. p. 212 , fig. $2 b$, in the centre from 2 nd level,

${ }^{3}$ I owe this identification to Mr Harden.

"Proceedings, vol. liv. p. 91, "a segment of a hollow rim."
} 
gravity to lay much stress upon it, it is interesting to note that all the cobalt blue La Têne beads from England and France that I have tested have specific gravity between $2 \cdot 28$ and $2 \cdot 34$, and several from the Eastern Mediterranean or Italy are 2:32, whilst the Saxon ones I have tested are 2485. The Covesea specimen at $2 \cdot 386$ is decidedly nearer the early beads. I therefore think that it was made before the Roman times, though it may quite possibly have been used by Romans." Jet annular bead, fig. 19, No. 12 (D 4). This is broken, but is finely polished, with a bevel on the inside. There is a similar bead in the National Museum from the Culbin Sands. "This appears to me to be a Bronze Age bead. Both the workmanship and the condition of the material make me place it at that date." Annular bead with some unknown substance inside, No. 13 (D 4). "This bead is exceptionally rough in manufacture. The heavy scratches over the surface are very unusual. I have seen them on jet and stone beads attributed to the Bronze Age, but I do not see why such a bead as this might not be made by an unskilled workman at any period." In Scotland such beads are not uncommon. The present specimen has parallels in the National Museum from Culbin, Luce Bay, and Traprain. No. 14 (D7). Fragment of a bracelet pierced for hanging and then again broken. It is beautifully worked. This habit of re-using bits of bracelets as pendants seems to have been particularly common in Morayshire, as there are several examples from the Culbin Sands.

Fig. 19, No. 11 (B 6). A chip of orpiment $\left(\mathrm{As}_{2} \mathrm{~S}_{3}\right)$. This identification was suggested by $\mathrm{Mr}$ Beck and confirmed by $\mathrm{Mr}$ Balsillie after experiment. It is a bright yellow glass-like substance, which is inclined to flake away. Mr Balsillie informs me that this is its natural condition and that it has not hitherto been reported from Scotland. It was used by the Romans both for pigment and for poison, but it would be rash to hazard a guess as to its significance on the present occasion. (B4). A smaller chip of orpiment.

Suggested date of some beads:-Bronze Age.-Nos. 1, 2, 12, 18, 19. Second Century A.D.-No. 9. Fourth Century A.D.-Nos. 8, 10, 15.

Lead.-Three pierced lead discs have been found suitable for netsinkers. "One has approximately $1 \cdot 1$ inch diameter and sp. g., 565. It is much corroded, which probably accounts for its low specific gravity. It is an unusual type and difficult to date." Probably it is of the Roman period.

Counters.-Numerous flat discs have been found suitable for counters, of many materials-sandstone, gneiss, shell, clay. Their use has not been determined, but they are common on many sites. ${ }^{1}$

Stone Files.-(D 4), a broken rectangle, 4 inches by 8 inch by 5 inch. It 
is well made and tapers at the ends. (D 4). Flat rectangle, 5.45 by 1.5 by 35. (B 4). Broken at both ends: about 1 inch square.

Iron.-(A 6). A Viking rivet. This appears to be the latest find in the cave. $C f$. Rivets from Carnan More, Otternish.

Samian Pottery (fig. 20).-All these pieces, except No. 2, are much worn. Nos. 1, 4, and 5 look as if this were deliberate. The rims 4 and 5

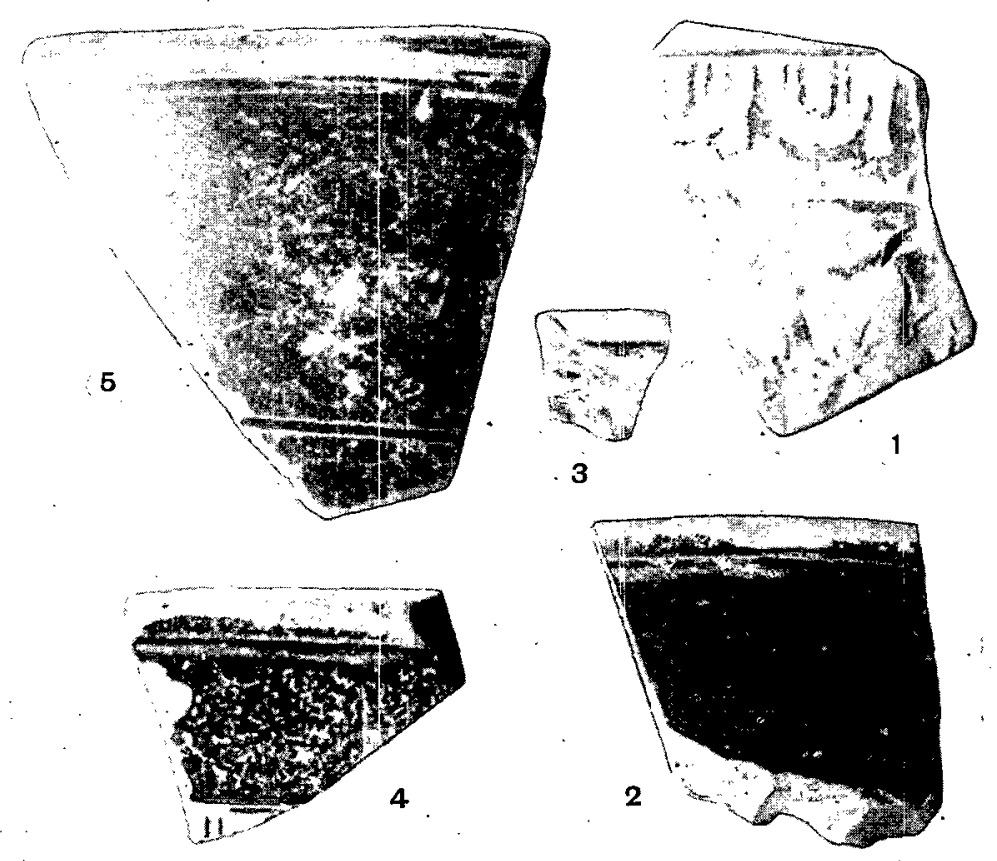

Fig. 20. Samian Ware from the Sculptor's Cave. (

seem to have been ground down by polishing. Pieces worn like this are to be seen in the National Museum from Traprain, Mumrills, and Newstead. The quality is rough and coarse. No. 1, Dragendorf 37. This shows a rather late pattern. No. 2, Dragendorf 37. The only fragment in good condition. It is a rim with a small pattern of divided circles. No. 3. Ornamented, but indeterminate. No. 4, Dragendorf 37. The rim of an even thicker pot than No. 1. It seems to have the beginning of an inscription. No. 5, Dragendorf 33. This is another worn rim.

Native Pottery of the Roman Period.-a. Fig. 21, No. 2. Rim. This 
is a polished wheel-made olla of second-century type. The clay is black and well levigated. Scattered over many divisions from $(B$ ) to $(C 7)$. Flat bottomed.

$\beta$. No. 3. Black, hand-made, soft ware, with indications of polishing. The rim is everted and decorated with finger-marks. It produces false rims as described ${ }^{1}$ in Skara Brae. Like the olla it is soft, crumbly, and well levigated. This pot seems to have been widely scattered. The height was probably about 8 inches.

$\gamma$. No. 1. This is yellowish in colour. The rim is everted and broken, the shoulders sloping. It is soft and inclined to split off in layers like a. Like $a$ and $\beta$ it is widely scattered. It was

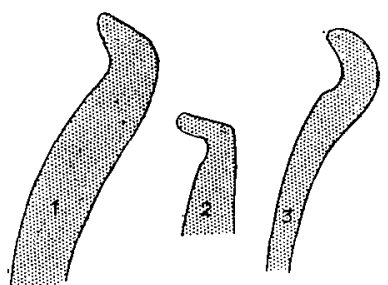

Fig. 21. Sections of Rims of Native Pottery from the Sculptor's Cave. $\left(\frac{1}{2}.\right)$ probably about 10 inches in height.

\section{Conclusions.}

Bronze Age.-Several archæologists have been quite shocked at the suggestion of a landing in Moray Firth. " Do not you know," said they, "that Mr Fox has said that there was absorption and not imposition in the north and east?" 2

Others are indignant on behalf of Ireland. "The Scottish Celts are always supposed to have come from Ireland." Have these supposers counted up the swords on the East Coast and considered the moulds at Traprain, including even a sword mould? However this may be, I have not the least doubt that there was one landing of foreigners, probably many, in the Moray Firth. More excavation is required before we can estimate their extent and importance.

Certain modifications may have taken place in the culture of these people on their way from Switzerland, but there is no evidence that these modifications took place in the British Isles.

The pottery is probably made of local clay; it has grown a little coarser, and may have lost a few nail-marks. In shape it is still completely Swiss.

The bracelets have still the distinguishing habit of being beaten ${ }^{3}$ from the inside out. Several examples shown me in the Zürich Museum were almost identical. From Balmashanner to Wester Ord they show little

${ }^{1}$ Childe, Proceedings, vol. lxiii. p. 269.

${ }^{2}$ Ant. Journ, vol. vii. p. 126. I have no idea what kind of burial-urn these people used. At present we are only concerned with their cooking-pots. Those in Covesea, at least, are in the pre-absorption state. As I read Mr Fox's theory it pre-supposes the existence of such a state.

${ }^{3}$ Cf. Grandson Courcelettes No. 24956 (cast), Zürich. 
variety of type. Note the other exotic article in our Eastern county hoards which has arrived without modification, the sword girdle from Braes of Gight. ${ }^{1}$

The Ring-money is the only purely western product in this settlement.

A curious feature is that Switzerland seems to have abandoned bone instruments at least by the Middle Bronze Age, and M. Vouga is inclined to think that the type represented by our Nos. 11 and 12 was confined at Bevaix at least to the earliest Neolithic. Either our people must have left Switzerland early and acquired the bracelets later, or they may have been a backward tribe who retained bone instruments until the Bronze Age.

There are great difficulties in the way of the inquirer after bone instruments. They do not appear in graves or hoards, and, even when they are present in settlements, archrologists may dislike them and throw them away. The bone instruments show a wide range of types, and they seem to have arrived unmodified.

Perhaps I may be allowed to mention the moulds for two socketed axes in the Elgin Museum, to suggest that if these Late Bronze Age people were traders they had come to stay.

I should also like to mention twelve flat axes ${ }^{2}$ in the same Museum from seven different sites, to suggest that the cave-dwellers were not the first invaders of the Firth, and Professor Childe has cited the Gallic Fort at Burghead to prove that they were not the last.

It is worth noticing that bone instruments of an apparently foreign type flourish at Heathery Burn, a canonical part of the invasion. ${ }^{3}$

\section{The Roman Period.}

Owing partly to the friable nature of the soil and still more probably. to the efforts of former explorers, it has not been possible to find any stratification in this period. We have, however, two dates established by the pottery, dated in the first half of the second century and by the coins from 337 to 354 .

With the aid of Traprain it has been possible to group certain articles with one or the other.

Second Century.

Five pieces of Samian and an olla.

Fig. 20, and fig. 21, No. 2.

Tags for belts.

Fig. 13, Nos. 15, 16, and 17.

${ }^{1}$ Proceedings, vol. xxv, p. 135.

${ }^{2} \mathrm{Mr}$ Callander has already noted that all the Scottish moulds for these objects come from our North-eastern Counties. Proceedings, vol. xxxviii. pp. $487 \mathrm{ff}$.

${ }^{3}$ Crawford, Ant. Journal, vol. ii. p. 33. 
Eight wry-necked pins.

Bronze sword guard.

Two glass beads.

The hearth at the bottom of the layer.

Fourth Century.

'The coins.

Two bronze pins.

Bronze nail-cleaners with geometric patterns. Fig. 17, Nos. 2 and 4 .

Bronze pin and grattoir.

Bone pins: one with geometric pattern.

Broken comb.

Blue beads.
Fig. 16, Nos.1,2,4, and 6 to 10 .

Fig. 15, No. 2.

Fig. 19, Nos. 9 and 16.

Fig. 4.

Figs. 22 and 23.

Fig. 16, Nos. 3 and 5.

Fig. 13, No.6, and fig. 17, No.7.

Fig. 18, Nos. 1 and 2.

Fig. 9, No. 1.

Fig. 19, Nos. 8, 10, and 15.

I do feel rather strongly that none of these articles are really suitable for cave-dwellers. Perhaps I am prejudiced by the extreme difficulty we had in detecting the bronzes. We kept losing excavation knives and entrenching tools. How could those people have kept nailcleaners and tweezers, and who would have the heart to clean nails in the Sculptor's Cave?

Scottish sites are not rich in little bronzes, perhaps because the dwellings were so dark. Half a dozen is a large number for a broch, and Borness ${ }^{1}$ heads the list of caves with five articles. On the other hand, as far as one can judge from the records, there was no lack of pottery. At Traprain, at any rate, there was masses. Our people had only three, or at most six, cooking-pots in their two periods.

Contrast this record with that of Wookey Hole, ${ }^{2}$ where there were quantities of Celtic pottery and seven pieces of bronze as a result of the first campaign. There, at least, is a clear case of occupation over a long period.

The pottery records of the Victoria Cave, Settle, ${ }^{3}$ are less satisfactory, but the bronzes there too are much too fine for cave men. It is now accepted that they cannot have been deposited by Celts fleeing from Saxons, but there may have been other refugees in Yorkshire in the second century with Brigantine wars and Pictish raids and may be some of our Covesea men reiving southwards. Perhaps they found tags and what not when Newstead and Birrens were hastily evacuated. It is also possible that the expedition of Severus in 210 caused the ladies of the Laigh to seek sanctuary, and that they died at Covesea

\footnotetext{
1 Corrie: Hunt, Clark, Proceedings, vol x. p. 490 ; vol. xi. p. 305.

2 Wookey Hole, Archceologia, vol. Ixii. p. 565.

3 Victoria Cave: Boyd Dawkins, Cave Hunting, p. 81.
} 
with their trinkets upon them. ${ }^{1}$ It emerged from Professor Bryce's report that there was a scarcity of adult males in the bones he examined.

With regard to the later period, the coins require no less explanation. Trade will hardly meet the case. The coins were ornaments rather than currency, and why here and nowhere else in Scotland? It is tempting to connect them with Picts south and over the Border in 367. Claudius tells of famous massacres in the far North two years later. ${ }^{2}$

If all this seems too fanciful, let it be remembered that there are a prodigious number of human bones to be explained and that nine of them show beheadings. ${ }^{3}$

This question is bound up with the date of the drawings on the walls. I hoped to republish those already published ${ }^{4}$ and add some others, but I have had to postpone this till later.

It is worth noticing that Samian pottery is the last dated find on the floor of the Cave of Constantine, ${ }^{5}$ whose signs are connected with the Wemyss ${ }^{6}$ signs and so with ours. Lastly, that Mr Diack dates the Auquhollie ${ }^{7}$ Stone 350 to 500, and one of our unpublished signs seems identical with his (two circles joined). Professor Childe pointed out that it was awkward to make unconnected strangers put up memorials or apotropaic signs years afterwards.

I am overwhelmed by the list of my obligations. Besides those already acknowledged, I owe much to the kindness of Museum Directors and staffs at Elgin, Aberdeen, Edinburgh, London, Cambridge, Oxford, Neuchatel, Zürich, besides counsel and inspiration from archæologists and scientists too numerous to mention.

\section{Human Bones.}

Professor Bryce kindly examined some of the human bones in 1928 . He made the same observation which was subsequently made independently by Professor Low that there was a preponderance of children's bones.

There were human bones in both layers, but many more in the mixed layer than in the bronze layer.

1 Professor Myres' pleasing suggestion.

2 Claudian, Panegyricus de Quarto Consulatu Fonorii Augusti, lines 31-33.

3 See p. 17. A local myth of cremation in the cave has arisen. It is without foundation.

4 Romilly Allen, Early Christian Monuments, vol. iii. p. 130; J. Stuart, Sculptured Stones of Scotland.

${ }^{5}$ Wace and Jehu, Proceedings, vol. xlix. pp. $237 \mathrm{ff}$.

- Wemyss, ibid., vol. xi. p. 107.

7 Diack, ibid., vol. lix. p. 257. 
EXCAVATION OF THE SCULP'TOR'S CAVE, COVESEA.

UNIVERSity OF ABERDEEN, Anatomy Department, MARISCHAL College, Aberdenn.

Comments on the Human Bones from the Sculptor's Cave, Covesea.

In this collection the human bones are so fragmentary and mixed that it is not possible to observe any characteristics of racial significance or differences between the bones of the respective layers. The large proportion of bones of young individuals is noteworthy.

18 th December 1930.

Alex. Low.

\section{Extract from Professor Tow's detalled Report on The Human Bones.}

(C7).-Small wisp of human hair-reddish-made up of strands eight inches long. Two plaits of human hair-reddish.

(B4).-Axis showing upper border of spine and laminæ cut off by a sharp instrument.

(C 4).-Atlas showing upper articular processes and anterior border cut off by a sharp instrument.

(C7).-Atlas showing lower left articular surface cut off by a sharp instrument.

(D 4).-Axis showing upper border of spine and laminæ cut off by a sharp instrument.

(D7).-Axis with upper border of spine and upper border of right lamina cut off right forward into odontoid process.

Axis where a complete cut has gone through the laminæ, pedicles, and body of the vertebra.

These six vertebræ indicate that the individuals must have been beheaded. ${ }^{1}$

REPORT ON THE ANIMAL BONES FROM 'THE SCULPTOR'S CAVE, COVESEA. By R. M. NeILL, M.C., M.A., Lecturer in Zoology, University of Aberdeen.

With the kind help of Miss Isobel Dean, B.Sc., I have examined this collection of animal remains.

There are 536 items in the collection, which is largely the customary débris of a midden or dump. ${ }^{2}$

\footnotetext{
1 Dr Dodgson discovered three more vertebre similarly cut.

2 This does not include a number of bones examined by Professor Ritchie.
} 
The bones are mostly much broken, and include remains of ox (Celtic ox), red-deer, roe, sheep, pig, dog, and fox, among mammals ; ${ }^{1}$ the bones of several gull-like birds and several bones from the head of a fish of the cod family, together with a single valve of oystershell.

Three bones were found definitely cut by a sharp and heavy implement such as an axe. In one group were five split pieces of long bones (red-deer), with remains of the marrow adhering.

The bones are not of great age and on the whole are in good preservation; a. few fragments are calcined and a number of others discoloured and blackened by fire. None were mineralised.

\section{REPORT ON TWO SPECIMENS OF BRONZE FROM SCOTLAND. By Mr O. Davies.}

The analyses were carried out by me at the Imperial College of Science, owing to the kindness of Professor Baker in putting Laboratory facilities at my disposal there.

Both specimens were badly rusted, and therefore I have put both the figures as found and the results when scaled to 100 per cent., in order that the character of the bronze may appear. The results, therefore, will not entirely represent the original composition, as copper and some other things are slightly soluble.

(C3 2nd) Section of Bracelet.

\begin{tabular}{|c|c|c|}
\hline \multicolumn{2}{|c|}{ Original Figures, per cent. } & Scaled. \\
\hline $\mathrm{Cu}$ & $41 \cdot 48$ & $74 \cdot 79$ \\
\hline Sn & $4 \cdot 42$ & $7 \cdot 97$ \\
\hline $\mathrm{Pb}$ & 8.74 & $15 \cdot 76$ \\
\hline $\mathrm{Zn}$ & tr. & tr. \\
\hline $\mathrm{Sb}$ & $\cdot 13$ & $\cdot 23$ \\
\hline As & ·30 & $\cdot 54$ \\
\hline $\mathrm{Fe}$ & $\cdot 39$ & $\cdot 70$ \\
\hline $\mathrm{Ni}$ & $\begin{array}{l}\text { tr. } \\
\text { No Ag, } \mathrm{Co}, \mathrm{B}\end{array}$ & tr. \\
\hline
\end{tabular}

This bronze is of a type that is very common in West Europe before Roman times, and goes back into Bronze Age III. or IV. There should be especially noticed the high lead percentage.

\footnotetext{
1 To this list should be added the horse and the beaver identified by Miss Bate. Mr Neill also called my attention to the worked deer tine.--S.B.
} 
EXCAVATION OF THE SCULPTOR'S CAVE, COVESEA. 209

(C 5) Needle.

Original Figures, per cent.

$\mathrm{Cu} \quad 70.57$

Sn 6.78

$\mathrm{Sb} \quad \cdot 29$

$\mathrm{Pb} \quad \cdot 14$

$\mathrm{Fe} \quad 32$

Co $\cdot 01$
Scaled.

$90 \cdot 35$

$8 \cdot 68$

.37

$\cdot 18$

.41

$\cdot 01$

No Ag, As, Bi, Zn, Ni.

An ordinary tin bronze. There should be noticed the fairly low percentage of tin, well below 10 per cent., which would be normal for pins and such objects that did not require to be very hard but which it would be surprising to find after the Early Bronze Age in use for swords, etc.

O. Davies.

Mr Davies notes that the percentage of lead at Covesea is less than that of the socketed axes at Heathery Burn Cave, 24:3 per cent, and he does not think that the two have the same source.

\section{Coins:}

There are nine Roman coins dated nearly to the middle of the fourth century. The limits are 337 to 354 . Of these coins eight show no signs of wear and tear and three are pierced.

Roman Occupation.-These two facts go to show that the coins were not the ordinary small change of the district. Therefore they were probably at some distance from an occupied Roman settlement. This conclusion is supported by the presence of five scraps of Samian pottery from four different bowls which have also been put to a new use. ${ }^{1}$ The olla alone would suggest a native pottery on Roman lines within the travelling radius of such pots, but, as it is unique, it cannot be taken to prove a Roman occupation of Morayshire, even in the second century.

Of the barbarian coins, it seems possible to discuss seventy-nine out of some two hundred and twenty. Their condition when found was deplorable, and it is rather a triumph for Mr Edwards that so many are legible.

Those which can be determined were confined to the following five types:-Gloria Exercitus, 3 ; Felicitas Temporum, 54 ; Victoria Augusti, 3 ; Roma, 2.

As at Lydney and Richborough, the Felicitas Temporum type is predominant.

VOL. LXV.

$$
{ }^{1} \text { See p. } 202 .
$$




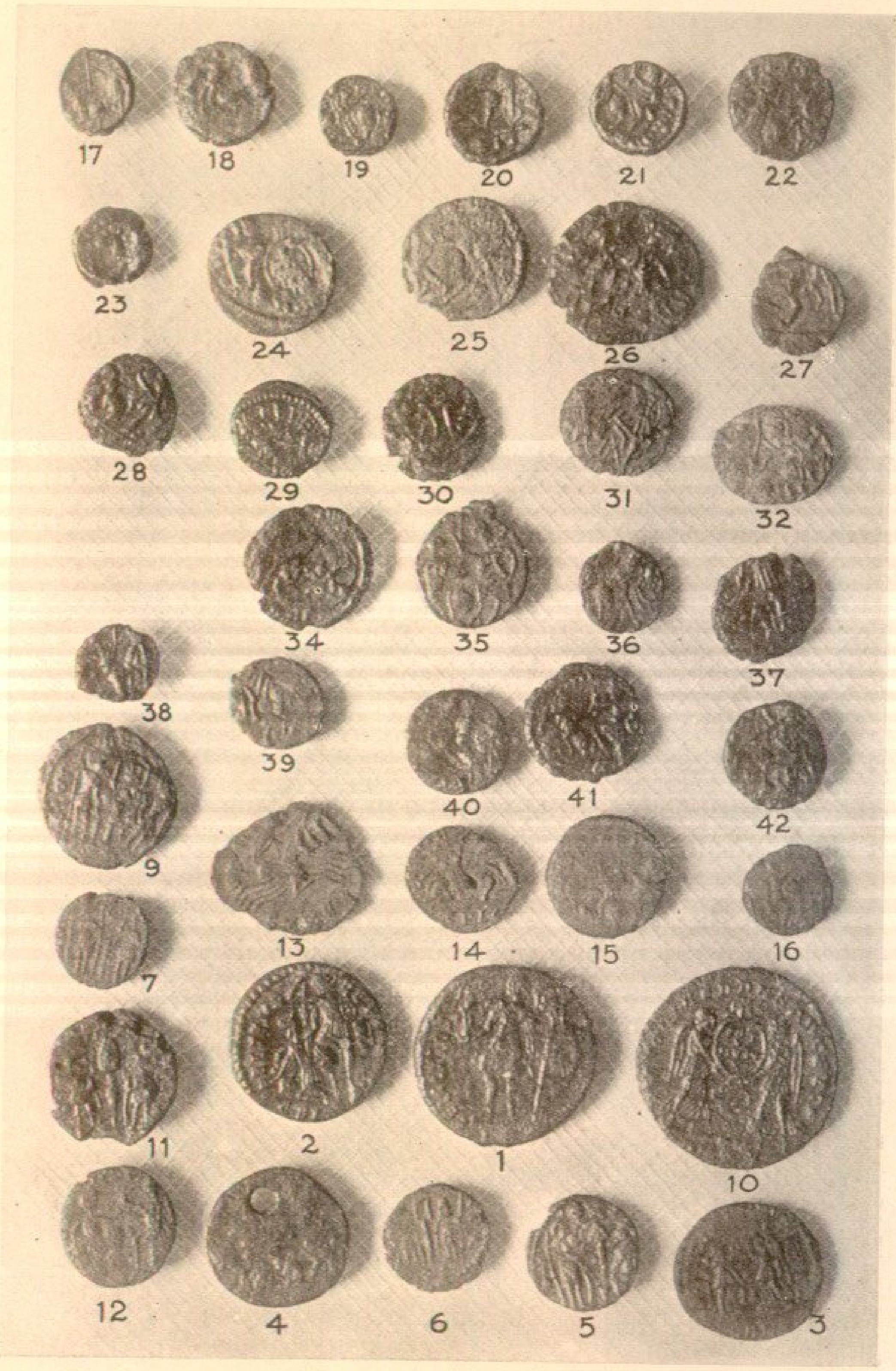

Fig. 22. Coins from the Sculptor's Cave. ( ${ }_{1}^{1}$.) 


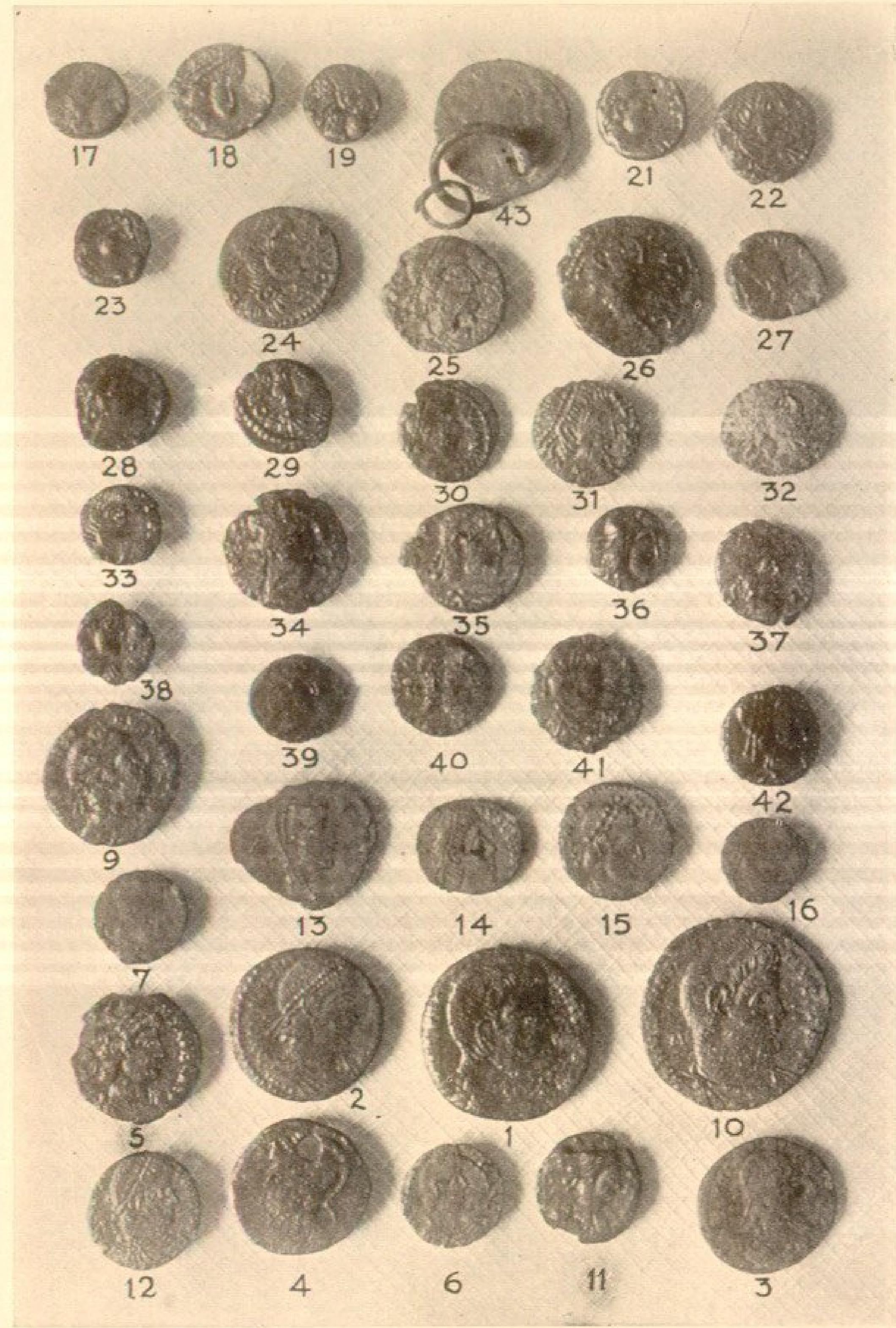

Fig. 23. Coins from the Sculptor's Cave. (1.) 
212 PROCEEDINGS OF THE SOCIE'TY, JANUARY 12, 1931.,

Mrs Wheeler, besides allowing me to see her collection before publication, has most kindly allowed me to study her manuscript. Our coins are larger, less fragmentary, less degenerate, and made on a different principle. Our smallest coin, No. 59, is bigger than the Lydney Minimissimi, and only about three of them were found at Covesea. I am only certain of clipping in one instance, No. 55.

At Lydney there was no complete coin found, and a good many of our coins have nothing missing. We have some variety of types.

Our coins are degenerate, but their idiosyncrasies have a certain attraction. Very few are mere nonsense, like so many of the Lydney coins. No. 48 is an exception (Nos. 44-79 at Elgin, not yet published).

Mr Casey explained to me that a large number of the Lydney coins are made by chopping up a rod of bronze. This causes impurities to concentrate in the middle, where the coin begins to degenerate. Our coins all split up the sides, showing that they were stamped out of a plate of metal.

Consequently there seems to be a good deal of difference in date between the two finds. Mrs Wheeler places her coins early in the fifth century. Mr Pierce thinks that our coins do not differ much in date from their prototypes, the last of which is dated 354. He also considers that they have a homogeneity of their own-that they form a group. The knowledge I have gained from describing them inclines me to think that he is right-that I should be able to distinguish one of the Covesea group from a Richborough coin of the period if $I$ found it in a barrow. If this is true, we may hope that we may one day discover from what English county our Caledonians filched them.

My thanks are especially due to Mr Pierce for his help with the barbarous coins. The Roman coins were identified by Sir George Macdonald.

Roman Coins :-

Figs. 22 and 23.

1. (B0) IM CAE MAGNENTIVS AVG. Magnentius. FELICITAS [REIPVBLICE]. Magnentius standing. In ex., TRP. Coh., viii. p. 9 , No. 5.

This coin has had some wear, but not much.

2. (C 8) DN CONSTAN[TIVS IVN NOB C]. Constantius Gallus. FEL TEMP REPA[RATIO]. In EX., cSL[C]. Coh., viii. p. 32 , No. 25.

In excellent condition. It seems almost new. Someone has started to bore a hole, but abandoned the effort.

3. (C 7) [CONSTA]N[TIVS] P F AVG Constantius II.

VICTORIAE [DD]AVGG CC Q NN. In EX., SARI.

Cf. Coh., vii. p. 484, No. 293.

Pierced. This coin has had some usage, but it is still quite sharp. 
4. (4 B) ROMA Period of Constantine I.

Wolf and twins.

Coh., vii. p. 330, No. 17.

Very much rubbed, but the type is quite clear. Pierced.

5. (A 5) [FL IVL CONSTANTI]VS NOB CAES. Constantius II.

GL[ORIA EXERCITVS]. Coh., vii. p. 455 , No. 02.

This is broken round the edges, but it seems to have been quite new when lost.

8. (C 3) [CONST]ANS P[F AVG] Constans I

VIC[T]O[RIAE DD] AVGG Q NN. In ex., TRP.

Coh., vii. p. 431, No. 176.

This is splitting up the middle, but the lettering is quite new. . Not illustrated.

9. (C 3) CONSTANTINVS IVN NOB C Constantine II.

GLORIA EXE[RCITVS]. Coh., vii. p. 377, No. 114.

Good condition.

10. (A 6) DN MAGNENTIVS P F AVG. Magnentius.

VICTORIAE DD NN AVG ET CAES. In wreath, VOT $V M V L X$. In ex., AMB.

Coh., viii. p. 19, No. 68 .

This is another new coin.

43. (B 4) Helmeted head of Roma and possibly ROM visible. Like the other Roma coin, this is much worn. It is pierced and hung on two wire rings, the ends of which overlap.

Barbarous Coins--

6. (C5) Gloria exercitus type.

Diademed head imitates the Constantius type; $c f$. No. 2 or 5 . There is a poor attempt to produce a legend. The relief is low, the design clear though weakly executed. Splitting.

7. (B 4) Same type.

Diademed head. A much robuster version than the last.

The reverse is nearer to No. 9 . Worn, broken, and split; no lettering visible.

11. (C 5) Same type; reverse nearer to No. 5.

It has achieved $C O$ in the right place, but the end of the inscription, though visible, is illegible. The head seems Constantinian.

The reverse, though lumpy, is vigorous.

12. (A 5) Fel. Temp.

The diademed head is very close to its prototype.

Reverse. - Signs of letters which may be correct. Design vigorous. Condition good. The coin was all there and only slightly rubbed.

13. (D 5) Head of Constantine I. veiled. ..... N I

Constantine in a chariot. Doubtful letters.

(Cf. Cohen, vii. p. 318, No. 760. Mattingly, Roman Coins, Pl. Ixiii., No. 6, p. 299.)

14. Fel.Temp.

A neat little head like No. $11 \quad V$ S P E

Reverse._An excellent charger E L TEM

There is a jagged hole in the middle.

15. (A 6) Fel. Temp.

Head seems bearded. STA. TIVS. Even the apices are clear. In ex., CPLG 
214 PROCEEDINGS OF 'THE SOCIETY, JANUARY 12, 1931.

16. (B 3) Fel. Temp.

Thin Constantinian head.

The reverse is faint but spirited.

17. (B 4) Fel. Temp.

The reverse and obverse do not go well together. The obverse lacks neck and chin and is fat.

18. (B 4) Fel. Temp.

The reverse is nearly complete and the figures are neat, if not thin.

This would seem to be the complete version of No. 17 as far as concerus the obverse. The diademed Constantinian head has

19. (B 4) Fel. Temp. become marvellously hairy.

Face going off right.

Reverse. - The legionary has become a few weak straggles on the left. The horse has lost his head, but his rump is magnificent.

20. (B 4) Fel. Temp.

Obverse broken.

Reverse.-Lumpy. Spear and falling horse visible Ex. U V

21. (B 4) Fel. Temp.

Diademed head. This face seems to be an intermediate type between the last three and No. 22, which is recognisably Constantinian.

22. (C 3) Fel. Temp.

Reverse.-Lumpy, horse going off left. Letters?

23. (B 4) Fel. Temp.

Constantinian gravitas has become a regular photograph stare.

Reverse:-The legionary is reduced to legs.

This head is similar to the last, but there is less of it. All that remains of the reverse is the horse. It seems as if he was consciously being used as a separate design. The coiner meant to make a horse's head framed in dots; at the last minute he

24. (B 4) Vic. Aug. squeezed in the rest of the animal.

Hardly shows any signs of degeneration. Diademed head. AVG in good lettering.

Reverse. -The right-hand Victory has been left out by careless

25. (A 4) Fel. Temp. striking.

R E P

The obverse is good.

26. (A 6) Fel. Temp.

Reverse.-The legionary is vanishing heavenwards. Pierced.

This head is barbarous, but belongs to the family.

27. (B 4) Fel. Temp.

Reverse.-Much blurred. T I $\mathrm{S}$ A V G

This is a very bad head. An extra nose has slipped under the chin. I V

Reverse.-The rump of the horse and some straggling legs. I believe that a tang has been deliberately hammered out of this coin, so that it might be attached as an ornament. Cf. Du Chaillu, vol. ii. p. 313. The Viking Age. Similar bronze wire beads to those there shown have been found in the cave. See p. 193. 
28. (3 A) Fel. Temp.

Diademed head, same type as 23.

29. (B 5) Fel. Temp.

Reverse.-Lumpy treatment; most of legionary lost.

This seems to aim at 24 , but only the back of the toga remains.

Reverse.-The Briton is falling off the best horse of the collection.

30. (B 3) Fel. Temp. $\mathrm{He}$ is a Celtic (?) triumph F E L E in the field.

Diademed and civilised head.

Reverse.-The legs of the legionary are again given the place of honour. The skirt of his tunic, his spear, and the rump of the horse are also visible.

31. (Not stratified) Fel. Temp.

Diademed head with the hair stylised.

Reverse. - The treatment is weak and skeletal, but most of the design is still here. 'The lines under the horse's tail are hard

32. (A 3) Fel. Temp. to explain.

Constantinian head.

The reverse design seems good, but the coin is much decayed. R E P

33. (A 6) Barbarous head, but of the same general type. Cf. No. 38. Only the face is on the coin.

Reverse.-Lost.

34. (Not stratified) Roma.

The wolf and twins are just visible. Pierced and in very bad

35. (A 4) Fel. Temp. condition.

Constantinian head, all present. R.S.T. Skeletal, Minoan-like reverse. The coin seems to have been hammered out at one end as if to facilitate attachment.

36. (B 3) Fel. Temp.

Obverse much better than reverse. Hatchet face. Thick heavy jaw. He has the air of a philosopher.

Reverse.-The shield on the right has grown enormous. The legionary's legs are weedy. The rump of the horse and the legs of his rider are visible.

37. (C 3) Fel. Temp.

The details of this head, especially of the chin, are very poor, straggling. i $\mathrm{V}$

In the reverse the design entirely fails to distinguish between the horse and the falling horseman.

38. (C 5) Fel. Temp.

Rather hairy Constantinian head.

The reverse is much more sensible in the photograph than in real life. Split.

39. (4 B) Fel. Temp.

Low relief ; head to the left, nearly worn away.

Reverse.--Severe disintegration has set in, but those slanting lines probably represent the tunic of the legionary, and there may be the legs of the horse to the left.

40. (B 5) Fel. Temp.

Fairly neat diademed head to left, but the nose appears to be snub. CON C A N 
216 PROCEEDINGS OF THE SOCIETY, JANUARY 12, 1931.

Reverse. - The design appears to have been complete, but the coin 41. (B 3) Fel. Temp. is worn. Pierced.

Diademed head with a long neck. Cf. Richborough II. Plate of coins. A V G

Good and complete reverse.

42. (B 3) Fel. Temp.

Good diademed head.

Reverse. - Gigantic legionary on the left; unfinished; hole in the middle of the horse.

NoTE.

The coins we have been dealing with have been fairly complete, and what remains is extremely decadent. The later examples (not yet published) are going the way of the Lydney coins. In that collection of over a thousand coins, all the flanges are too big for the coins, and no single design is complete. In our collection in the first of the fat series (Nos. 17-20), the gentleman has lost his chin. Degeneration, like old age, seems bound to incline to the fat or the lean. Let us recall the pillow-like horses of Late Mycenæan seals. These published horses specialise in enormous rumps. There is another breed of horse in the collection which fades away into a curve, e.g. No. 57, and ends as a straight line, as in No. 48. 